DEPARTMENT OF THE INTERIOR

Albert B. FAll, Secretary

UNited States GeOLOGICAL SURVeY

George Otis Smith, Director

Professional Paper 129

\title{
SHORTER CONTRIBUTIONS TO \\ GENERAL GEOLOGY
}

1921

DAVID WHITE, ChIEF Geologist

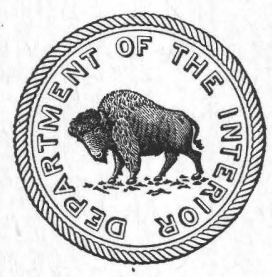

WASHINGTON

GOVERNMENT PRINTING OFFICE

1922 


\title{
THE FLORA OF THE CHEYENNE SANDSTONE OF KANSAS.
}

\author{
By Edward Wilber Berry.
}

\section{INTRODUCTION.}

The present study is based on collections made by Hill in 1894, Ward and Vaughan in 1896, Ward, Gould, White, and Cain in 1897, and Lee in 1919. These collections were very extensive, but the bulk represented small fragments of the more abundant species, such as the Sequoia and Sapindopsis. The flora itself as at present known consists of a very small number of species.

The Cheyenne sandstone comprises about 100 feet of gray to yellow friable quartz sandstone with subordinate lenses of dark shale. The sandstone ranges from fine to coarse and contains a few layers of quartz and chert pebbles. It is in the main only slightly consolidated and is very friable and easily eroded. The bedding is extremely irregular and discontinuous, and cross-bedding is obvious throughout and in places extremely pronounced. Logs of silicified wood and Cycadeoidea minuta from these beds were recorded by Cragin. ${ }^{1}$

The Cheyenne sandstone rests upon " Red Beds" of supposed Permian age and is overlain by the Kiowa shale-shallow-water and lagoon deposits of alternating layers of marl and bituminous clay shale, with a marine fauna that includes many species characteristic of the Washita group of the Texas Cretaceous.

The invertebrates are said by Twenhofel to number about 50 species, of which the following are some of the commoner forms:

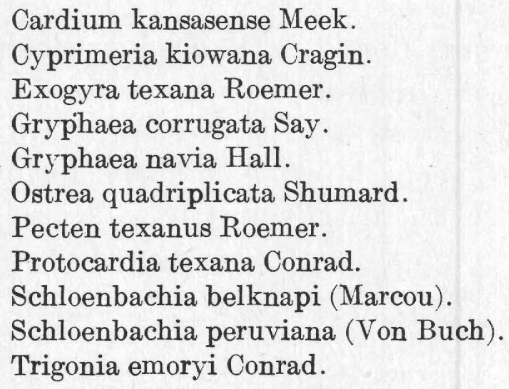

1 Cragin, F. W., Washburn Coll. Lab. Nat. Hist. Bull., vol. 2, pp. 35-66, 1889.
In some places the Tertiary overlies the Kiowa; elsewhere the following units in ascending order have been recognized by Gould: Spring Creek clays, Greenleaf sandstone, Kirby clays, and Reeder sandstone. The names are those proposed by Gould and Cragin and have not been formally recognized by the United States Geological Survey. These units are chiefly local phases or lentils in the Kiowa, of little significance except as indicative of local and more or less contemporaneous variations in conditions of deposition, with perhaps a basal member of the Dakota sandstone represented in the "Reeder."

\section{HISTORICAL SUMMARY.}

The term "Dakota group" was first used in 1861 by Meek and Hayden ${ }^{2}$ for the lower portion of their section of the Cretaceous of $\mathrm{Ne}$ braska, corresponding to No. 1 of the classic Meek and Hayden Upper Missouri section. ${ }^{3}$ This term or simply Dakota or Dakota sandstone has subsequently been used in innumerable references to local geologic sections throughout the West. The assumption that the Upper Cretaceous of that whole region contained two persistent sandstones-the Dakota at its bottom and the Fox Hills near its top-and the fancied recognition of these sandstones over a wide area have caused much of the confusion and controversy that have arisen over the interpretation of the western Cretaceous.

As originally understood the term Dakota was applied to the pre-Benton Cretaceous, no Lower Cretaceous being then recognized in that region. Unquestionably the typical Dakota sandstone represents the littoral or marginal deposits of the transgressing Benton sea, but that there are similar and somewhat earlier continental or marginal sandstones in

2 Meek, F. B., and Hayden, F. V., Acad. Nat. Sci. Philadelphia Proc., vol. 13, p. 419, 1861.

${ }^{3}$ Hall, James, and Meek, F. B., Am. Acad. Mem., vol. 5, p. 405, 1856. Meek, F. B., and Hayden, F. V., Acad Nat. Sci. Philadelphia Proc., vol. 8, p. 63,1856 . 
Kansas, Colorado, the western Black Hills, and presumably elsewhere in this region has been pretty well known for a number of years. Their exact age has been a matter of considerable differences of opinion.

The history of paleobotanic discovery of the so-called Dakota flora has been given in Lesquereux's three memoirs and need not be recounted here except to point out that the collections, a study of which resulted in the identification of over 400 species of plants, were made at different times and places by a number of different collectors, who, as in so much of the early exploratory work in the West, paid little attention to stratigraphic position or locality. Any yellowish or reddish sandstone with impressions of dicotyledonous leaves was Dakota in age, and for a large number of species "Dakota group of Kansas," or at most the county from which the specimens were collected, is all we know of the whereabouts of the outcrop.

Apparently the first to notice marine fossils at the base of the red Cretaceous (Dakota) sandstones was Le Conte. ${ }^{4}$ Cragin, while at Washburn College, Topeka, Kans., did much work upon the Cretaceous and published many short paleontologic papers. In 1890 he described a cross-bedded sandstone (the Cheyenne sandstone) which underlay marine beds in southern Kansas and which he considered to be related to the Potomac, Tuscaloosa, Trinity, and "Atlantosaurus beds," and the next year he published the statement that the Cheyenne sandstone was probably of the same age as the Trinity of Texas, the Potomac of the Atlantic Coastal Plain, and the Wealden or Purbeck of Europe. Invariably in his discussions he used the term Comanche as the interchangeable equivalent of the European Neocomian.

The first definite announcement of the flora contained in the Cheyenne sandstone was made by Hill, ${ }^{5}$ who recorded the following species from collections made by Hill, Gould, and Shattuck in 1894:

Rhus uddeni Lesquereux.

Sterculia snowii Lesquereux.

Sassafras mudgii Lesquereux.

4 Le Conte, J. L., Notes on the geology of the survey for the extension of the Union Pacific Railway, Philadelphia, 1868.

5 Hill, R. T., Discovery of a dicotyledonous flora in the Cheyenne sandstone: Am. Jour. Sci., 3d ser., vol. 49, p. 473, 1895; On outlying areas of the Comancheseries in Kansas, Oklahoma, and New Mexico: Idem, vol. 50, pp. 205-234, 1895.
Sassafras cretaceum obtusum Lesquereux.

Sassafras n. sp.

Glyptostrobus gracillimus Lesquereux.

Sequoia sp. (cones).

Cragin's conclusions were given in a paper published in $1895,{ }^{6}$ in which the section is given as follows:

Kiowa shales.

Champion shell bed. $\left\{\begin{array}{l}\text { Elk Creek beds }\left\{\begin{array}{l}\text { Stokes sandstone } \\ \text { Lanphier shale. }\end{array}\right. \\ \text { Corral sandstone. }\end{array}\right.$

From the "Elk Creek beds" he recorded Sterculia snowii, Sassafras mudgei, Sassafras cretaceum, Sassafras sp., Rhus uddeni, Sequoia sp., and Glyptostrobus gracillimus. ${ }^{7}$ Only the first two of these are contained in the collections studied by me.

Other contributors to the subject prior to 1900 were Mudge, Prosser, Jones, Stanton, and Gould. Their results are not pertinent to my present purpose beyond the fact that they show conclusively the presence of a sandstone, the Cheyenne, containing the remains of a land flora in southern Kansas beneath a marine series, the Kiowa shale, carrying a fauna that is correlated with that of the Washita group at the top of the supposed Lower Cretaceous section of Texas as elaborated by Hill.

During his residence in Kansas Twenhofel studied the Cretaceous of the central part of the State, and in a brief paper ${ }^{8}$ published in 1917 he confirmed Cragin's earlier results ${ }^{\circ}$ that a situation identical with that of southern Kansas prevails in central Kansas. In a more recent article ${ }^{10}$ he contends that the Dakota of Kansas and the Washita group of Texas are of the same age, and that both the CheyenneKiowa-"Medicine beds" sequence of southern Kansas and the Mentor-Dakota sequence of central Kansas should be referred to the Comanche series.

The "Dakota flora" of the Denver Basin has recently been revised by Knowlton. As a result of field work by Lee and Cannon during 1916 it has been shown ${ }^{11}$ that the formation from which Lieut. Beckwith collected the "Dakota" plants from Morrison, Colo., that

6 Cragin, F. W., A study of the Belvidere beds: Am. Geologist, vol. 16, pp. $357-385,1895$.

7 Idem, p. 367, quoted from Hill.

8 Twenhofel, W. H., Kansas Acad. Sci. Trans., vol. 28, pp. 213-223, 1917. ${ }^{9}$ Cragin, F. W., Am. Geologist, vol. 16, pp. 162-165, 1895.

10 Twenhofel, W. H., Am. Jour. Sci., 4th ser., vol. 49, pp. 281-297, 1920.

${ }^{11}$ Lee, W. T., Am. Jour. Sci., 4th ser., vol. 49, pp. 183-188, 1920 
Lesquereux described is the same as that described by Richardson ${ }^{12}$ in 1915 as the Purgatoire formation and referred to the top of the Lower Cretaceous. This formation has also frequently been called "Lower Dakota." Below this, in the type section at Morrison and within the Morrison formation ("Atlantosaurus beds") as originally described, there is about 100 feet of friable sandstone and shale containing traces of a flora similar to that found in the overlying sandstone. This flora has been discussed by Knowlton, ${ }^{13}$ who quite rightly concludes that it is Upper Cretaceous.

I am not concerned in this paper with the taxonomic proposals regarding what shall be the stratigraphic limits of the Dakota, but solely with the general relations and their bearing on the geologic history of the region and the boundary between Lower and Upper Cretaceous.

It has been customary for geologists, particularly those who had a leaning toward philosophy, to postulate a rhythm of positive and negative movements of the strand by which the boundaries of the different systems could readily be determined. There may be some physical basis for this conception, but it should be recalled that all series of changes can be considered rhythmic, with some elasticity in the application of criteria, and I am one of those reactionaries who believe that, however imperfect the scheme as devised for the region first and longest studied, namely, Europe, the classic names and approximate limits of the systems should be adhered to; for, after all, the best classifications, whether of geologic time or of formations, igneous rocks, or organisms, are those which are most easily understood and used.

Time is continuous, time boundaries are always subjective, and the time-honored terms Permian or Triassic or "Lower Carboniferous" or Lower. Cretaceous are to me as essential to clear thinking and the interchange of geologic ideas among nations as the minutes, hours, and days of the current time scheme, however illogical these may seem in sidereal astronomy.

According to the customary American scheme the Lower Cretaceous should be con-

${ }_{12}$ Richardson, G. B., U. S. Geol. Survey Geol. Atlas, Castle Rock folio (No. 198), 1915.

${ }^{13}$ Knowlton, F.H., Am. Jour. Sci., 4th ser., vol. 49, pp. 189-194, 1920. $32333^{\circ}-22-16$ sidered to have ended with the withdrawal of the Lower Cretaceous sea and the Upper Cretaceous to have begun with the initial transgression of the Upper Cretaceous sea. Where the interval between these two events was long, with continental deposition, much confusion and difference of interpretation results. A classic instance of such differences is the controversy over the boundary between the Cretaceous and Tertiary in the Great Plains and Rocky Mountain region of North America, which the Tertiary sea was so inconsiderate as not to invade. If geology at its inception had concerned itself chiefly with continental deposits and land plants and animals and had ignored marine formations and life the situation would be exactly reversed, and the marine sediments would probably be those in dispute.

On none of the continents, so far as I can discover, did the sea complete a cycle of invasion and withdrawal of what might be called the first magnitude during the Lower Cretaceous epoch. In the Atlantic Coastal Plain no marine Upper Cretaceous deposits earlier than the European Turonian are known except in the Texas area, where marine formations representing a part but not all of the Lower Cretaceous of Europe advance haltingly from the south. The oldest of these formations is the Trinity, which in my judgment is nowhere as old as the Neocomian of Europe. This is followed by the Fredericksburg group, which Hill called Neocomian but which contains a younger fauna. If one disregards Böse's correlations of the Mexican Cretaceous on the ground that Mexico is too remote from the north Texas-Kansas area, Whitney's studies of the fauna of the Buda limestone not only clearly show its Cenomanian age but also show that it is late Cenomanian. Similarly the fauna of the Georgetown limestone is Cenomanian. (Whitney has refrained thus far from making any intercontinental correlations.) It is a striking confirmation of this correlation that the Buda limestone near Austin and hence in the region of more continuous marine conditions than farther north should be immediately overlain by the Turonian Eagle Ford formation. The problem of working out the interfingering of formations between north and central Texas is largely a problem of invertebrate paleontology 
and would not be mentioned in the present connection if it were not for the necessity of showing that the correlation of the Texas Comanche series with the Lower Cretaceous of Europe is incorrect and can not hope to be ultimately accepted, and because this problem is so intimately bound up with the age of the Cheyenne sandstone.

If there is no marine Lower Cretaceous in Kansas, as I contend, our ideas of the sequence of events from late Lower Cretaceous time into the Upper Cretaceous require to be very greatly modified.

With regard to Twenhofel's proposal to refer the Mentor and Dakota of central Kansas to the Comanche, all that I can say is that while he and before him Cragin and others have written about the Dakota flora, this term is altogether meaningless stratigraphically, except that it denotes in a most general way a change in facies between Lower and Upper Cretaceous floras. The flora of the Cheyenne sandstone, and I presume that in the Mentor formation as well, is no more like that of the Woodbine sand than the Woodbine flora is like that of the several formations of the Montana group, and the reference of the Dakota sandstone-that is, the post-Mentor Dakota sandstone of central Kansas-to the Lower Cretaceous if correct would of necessity carry with it the Bingen sand of Arkansas, the Tuscaloosa formation of Alabama, the Black Creek formation of the Carolinas, and the Magothy formation of New Jersey and Maryland, against whose correlation with the Senonian of Europe by paleozoologists I have been arguing for years, with not very great success.

\section{LOCALITIES.}

All the localities from which fossil plants were collected in the Cheyenne sandstone are in the immediate vicinity of Belvidere, Kiowa County, Kans. (See Pl. XLVI.) I give below a transcription of the locality numbers, with the names of the collectors and dates, taken from the United States Geological Survey's records. There appears to be some confusion in the two collections numbered 2224, nor do I have locality numbers for the material collected by Ward and Vaughan in 1896. These defects in the record are immaterial, however, for there is no doubt that all the material studied came from the Cheyenne sand- stone in this immediate region. Many of the numbers are duplications of identical outcrops and are given only as a matter of record.

773. Black hills near Belvidere; collected by Hill, Gould, and Shattuck, 1894.

2217. Osage Rock at Belvidere, from Nos. 1 and 2 of Hill's section; collected by O. L. Cain, 1897.

2218. One and one-half miles northwest of Belvidere, from No. 3 of Hill's section; collected by Ward and Gould, 1897.

2219. Same as 773. Stokes Hill, 100 yards south of the National Corral; collected by Ward and Gould, 1897.

2220. Stokes Hill, the most northeasterly of Hill's localities; collected by Gould, 1897.

2221. Thompson Creek near the flume, 2 miles northwest of Belvidere; collected by Ward and Gould, 1897.

2222. Champion (Wildcat) Draw, three-fourths mile south of Belvidere; collected by Ward, Gould, and White, 1897.

2223. Same locality and collectors as 2222 , from the "Lanphier shales."

2224. Near Medicine Lodge River, 2 miles west of Belvidere (original locality of Ward and Vaughan in 1896); collected by Ward and Gould.

2224. Champion (Wildcat) Draw, right (east) branch, in "Lanphier shales," half a mile south of Belvidere; collected by Ward and Gould, 1897.

2225. One mile southwest of Belvidere, in a draw ("Lanphier shales"); collected by Ward and Gould, 1897.

2226. About $2 \frac{1}{2}$ miles due west of Belvidere (fern bed of 1896); collected by Ward and Gould, 1897.

2227. Hills between Spring Creek and Soldier, 4 miles northeast of Belvidere; collected by Ward and Gould, 1897. 2228. Champion (Wildcat) Draw, right (east) branch, "Lanphier shales," half a mile south of Belvidere; collected by Ward and Gould, 1897.

2229. Left bank of middle branch of Champion (Wildcat) Draw, half a mile south of Belvidere; collected by Ward and Gould, 1897.

2230. Draws north of Belvidere ("Lanphier shales"); collected by Ward and Gould, 1897.

2231. Right bank of middle branch of Champion (Wildcat) Draw, half a mile south of Belvidere; collected by Ward and Gould, 1897.

2232. Osage Rock at Belvidere, "Stokes sandstone" below the so-called Champion shell bed; collected by Ward and Gould, 1897.

2233. First draw west of Champion (Wildcat) Draw, half a mile south of Belvidere; collected by Ward and Gould, 1897.

7405. Wildcat Draw, near Belvidere; collected by W. T. Lee, 1919.

7406. Osage Rock, near Belvidere; collected by W. T. Lee. 1919.

\section{CHARACTER OF THE FLORA.}

The flora of the Cheyenne sandstone as disclosed in the present study numbers but 23 species. It comprises four ferns representing the families Polypodiaceae and Gleicheniaceae, and all four are representatives of widely 


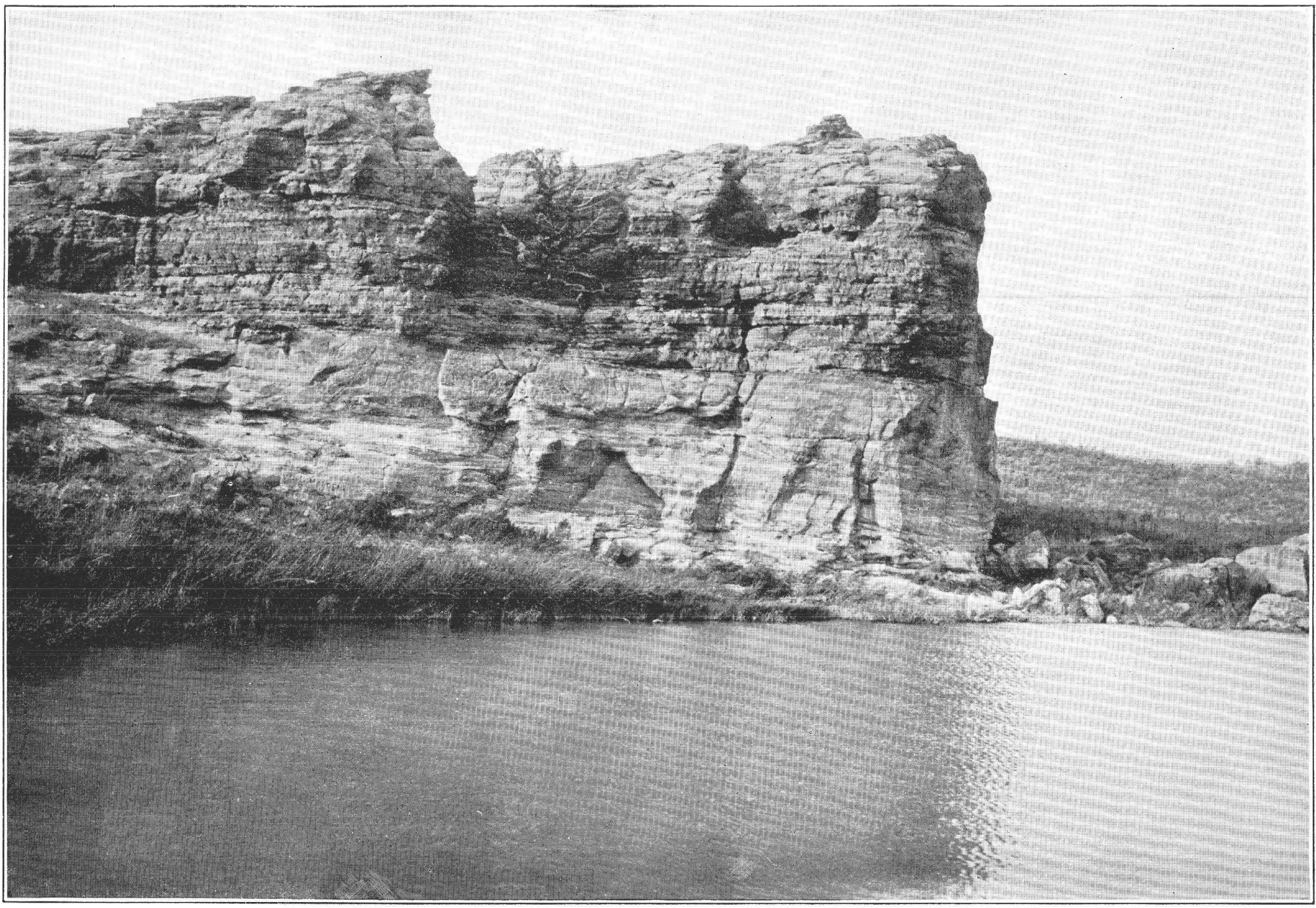

OSAGE ROCK, ABOUT 1 MILE NORTH OF BELVIDERE, KANS, 
ranging and more or less well known Cretaceous types. The collections include a supposed cycadophyte seed, but this is of doubtful relationship. There is also a fragment of a trunk of the genus Cycadeoidea, which is of somewhat uncertain value, as its exact stratigraphic position has been questioned. There are four coniferophytes and eleven angiosperms. One of these is a supposed monocotyledon, ten are dicotyledons, and there are two forms of uncertain botanic relationships.

The dicotyledons represent the orders Sapindales, Malvales, Thymeleales, and Umbellales and are remarkable for the total absence of a large number of elements generally found in floras of this age. This absence can not be wholly explained by accidents of preservation and discovery and is due, I believe, to the peculiar ecologic grouping resulting from the environment.

The arenaceous portions of the Cheyenne sandstone are very conspicuously cross-bedded. The material is very friable, and the vegetable remains are embedded in all sorts of positions and curled as they are when covered in a dry condition by wind-blown sands. All are coriaceous forms, and the abundant Sequoia cones all have their scales shrunken and widely distended as in thoroughly desiccated modern cones. They appear to have blown about and collected in hollows along with the coriaceous leaves that are found in association with them. With a single exception the ferns are found in the clays and evidently were confined largely to stream banks.

The variety of plants in such situations may have been larger than the discovered flora indicates, but it would seem as if in collections so extensive there should be some traces of the other plants preserved if they were growing near at hand.

Although the flora is too small and too remote in time from existing floras to afford satisfactory ecologic data, it does furnish some suggestions. It seems to me to indicate a warm and more or less arid climate, with a sparse vegetation. I picture this vegetation as of meager variety and as having been confined largely to the region of watercourses between which were larger areas of sand-hill or beachdune country over which the dried leaves and fruits were blown, collecting in the hollows and becoming covered by wind-blown sands. The clay lenses - for example, Cragin's "Lanphier beds"-are waterlaid and might represent seasonal rainfall and flood-plain or playa deposits or normal stream sedimentation, and it is possible that some of the sands had a like origin.

There is no evidence of aridity in any of the Cretaceous floras with which the Cheyenne sandstone flora may be compared, whether such comparisons are made with the Patapsco and Fuson floras, on the one hand, or the Woodbine, Dakota, and Tuscaloosa floras, on the other. I believe, therefore, that the Cheyenne flora does not represent general conditions but is purely an expression of the local environment and perhaps represents a wide sandy coastal plain or fluctuating beaches backed by dunes, and that farther inland a more varied and normal flora probably existed throughout the period when the shallow sea was migrating back and forth across southern Kansas.

A sample of the Cheyenne sandstone was submitted to Mr. Marcus I. Goldman, who has kindly furnished the appended observations:

Macroscopic examination.-A solid but friable finegrained sandstone of a pale lavender-brown color characteristic of moderately carbonaceous sandstones. No lamination. Contains curled and wrinkled leaf impressions suggestive of deposition in a dry condition, hence in wind-blown sand.

Mechanical analysis. - The rock could be easily rubbed down into its constituent grains. On sieving these divided as follows: Fine sand through 60 on 100 mesh, 12.9 per cent, $0.45-0.26$ millimeter; very fine sand through 100 on 200 mesh, 82.2 per cent, 0.26-0.04 millimeter; extra fine sand through 200 mesh, 4.9 per cent, less than 0.04 millimeter. Microscopic examination showed that the two finer parts contained thoroughly disintegrated grains. The coarsest, however, consisted largely of compound grains which yielded slowly to disintegration, so the following rough figures may be taken: Fine sand, 5 per cent; very fine sand, 90 per cent; extra fine sand, 5 per cent. In either case the great predominance of the very fine sand is obvious. This predominance of a single size at once suggests wind action, but comparison with dune sands (cf. my paper on the Catahoula sandstone, ${ }^{14}$ where several analyses are assembled) shows that the maximum is in the size next finest to that which forms the maximum in typical dune material. I have looked up the large collection of analyses given by Udden ${ }^{15}$ and find that in this character the sample resembles the finer sand carried by the wind out of other deposits. Thus it corresponds with only two of his dune sands-No. 219, which is the finest material gathered at the crest of a dune, and No. 248, from a blown field.

14 Goldman, M. I., Petrographic evidence on the origin of the Catahoula sandstone of Texas: Am. Jour. Sci., 4th ser., vol. 39, p. 269, 1915.

15 Udden, J. A., Mechanical composition of clastic sediments: Geol. Soc. America Bull., vol. 25, pp. 655-744, 1915. 
On the other hand, the majority of samples of what he calls incipient wind-blown sand, which is sand blown out of other deposits, have this composition, as do also his lee sands, which are the finer material blown beyond the body of a dune.

Microscopic examination.-(I) Thin section: Three characters are conspicuous in the thin section of the original rock, namely, (a) its porosity, which is evidently primarythat is, not produced by grinding the thin section-and is a character of wind-deposited material; ${ }^{16}(b)$ the angularity of most of the grains; $(c)$ the absence of a recognizable deposit of secondary quartz on the outside of the grains. In many cases it can be definitely proved, by the presence of inclusions throughout the grain, that there is no outer coat of secondary quartz, and the rough angularity of the grains does not suggest secondary growth, which tends to restore crystal form, but, if anything, rather solution. (II) Disintegrated sand: The disintegrated material can be studied to greater advantage because it can be immersed in liquids of different indices of refraction. Thus by immersing in a liquid of index about 1.55 the inner structure of the quartz grains and any possible boundary between nucleus and secondary quartz can be more readily recognized. Immersing in a liquid of index about 1.65 , on the other hand, brings out brilliantly the surface form and texture. Much more could be observed, especially in the latter liquid, than the time at my disposal permitted, but I can make the following generalizations: (a) None of the portions, not even the coarsest, reveal any unusual abundance of rounded grains; rather the opposite. (b) The surface of grains is not frosted, as is characteristic of wind-blown sand, nor pitted, as if subjected to much solution, but rather rough and chipped-looking, as might be the result of mechanical wear. (c) Under the favorable conditions afforded by immersion in a liquid of index about 1.55 , no secondary silicification could be detected. (d) In the finest size a few very small well-rounded grains were found, the smallest having a diameter of about 0.025 millimeter and being exceptionally perfectly rounded. Such a grain could probably be produced only by prolonged wind action. ${ }^{17}$

The main problem of fact, in spite of these observations, still concerns the cause of the present form of the grains. Secondary silicification is often very veiled, and in the absence of comparative studies I am not prepared to commit myself as to the possibility of solution having acted on the grains. These two factors affect not only the form but also the size of the grains. However, the coherence of the observations made favors the belief in their correctness. They lead to the following conclusion:

The portion of the Cheyenne sandstone represented by this sample is nothing like an eolian deposit in an arid region, nor even a part of a permanent dune area in a humid climate, but merely an accumulation of material blown by the wind out of a deposit of some other origin. Only an extensive field study could disclose the main accumulation from which this is separated and other possible associated facies and lead to a complete and satisfactory interpretation. From the roughness of the sand grains I would be inclined to assume rather a delta than a beach deposit as the dominant type. The very

16 Goldman, M. I., op. cit., pp. 280-281.

${ }_{17}$ Idem, pp. 271-272. small, perfectly rounded grain noted appears entirely out of place as the product of the conditions under which the sandstone seems likely to have been formed and must therefore be assumed to be the product of an earlier cycle in the history of the grain, unless it is assumed that in a deposition of secondary silica the larger grains have been favored so that only the smallest grains retain their original form; but this seems to me incompatible with the uniform size of the larger grains.

As brought out in the paper on the Catahoula sandstone there are many more factors that might have been considered, but being limited in time and having no assistance for such work I have selected the few that seemed most rapidly determinable and most important.

A single sample whose position in the local section is unknown can be conclusive only for that one sample. The foreset bedding of which I have seen pictures suggests delta deposition, but no one has made field studies of the Cheyenne sandstone with the object of determining the origin of the sediments or the method of sedimentation, and Mr. Goldman's report is therefore chiefly significant in indicating what definite results might be obtained in this region of an oscillating Cretaceous strand by a careful study of the problem.

The plants and their method of occurrence conclusively indicate a sparse vegetation, at least seasonal dryness, and accumulation by the wind. This I am sure was a local condition, as previously stated. Whether these facts do or do not indicate beaches, interstream sand hills, or delta deposits can be determined only by future studies.

\section{AGE OF THE FLORA.}

Ignoring for the present the general relations and the implications resulting from the age of the overlying Kiowa shale or the supposed equivalent beds in Texas, as discussed in the preceding section, and considering only the evidence of the fossil plants, I may note that ten of the 23 species are positively identified as "Dakota" forms and two additional species are tentatively so identified. Four others are peculiar to the Cheyenne sandstone. The type localities of the remaining seven species were the Cenomanian of Bohemia (one species), the Atane beds of Greenland (two species), and the Patapsco formation of Maryland (four species).

Of the so-called Dakota forms in the Cheyenne flora the following species were previously known from only the "Dakota": Cladophlebis dakotensis (Lesquereux), Cycadeospermum line- 
atum Lesquereux, Sequoia condita Lesquereux, Abietites ernestinae Lesquereux, Sterculia mucronata Lesquereux, and Sassafras mudgii Lesquereux. Of these the first two were found near Delphos, Kans.; Sequoia condita, one of the most abundant forms in the Cheyenne sandstone, was known simply from "Kansas" and might really have come originally from the Cheyenne sandstone; Abietites ernestinae was from Decatur, Nebr.; Stercutia mucronata was from Ellsworth County, Kans.; and Sassafras mudgii was recorded from Salina River, Kans., and Evans quarry, S. Dak. According to Stanton the outcrops of the Dakota sandstone at Delphos, in Ellsworth County, and along Salina River, in Kansas, and at Decatur, Nebr., are in the upper part of the Dakota, the beds at Decatur being within 300 feet of the top. Hence the species common to these localities tend to emphasize the transitional character of the Cheyenne flora.

Five of the remaining six species common to the Dakota are of still more value in that they have all been recorded from other regions where the age is less a matter of doubt. The sixth, Asplenium dicksonianum Heer, is of slight value in this connection, as it is probably a composite species. It has been recorded from both older and younger formations, namely, Tuscaloosa, Raritan, Patapsco, Lakota, Kome, Atane, Kootenai, and the Upper Cretaceous of Sakhalin Island. Gleichenia nordenskiold $i$ was described originally from material collected in the Kome beds of Greenland and identified by Lesquereux in specimens from the Dakota at Fort Harker, Kans. I have identified the Cheyenne sandstone specimens as this species because they are identical with those described under that name by Lesquereux, but neither these nor Lesquereux's specimens can be distinguished from another of Heer's nominal species of Gleichenia, namely, Gleichenia zippei, which has been recorded all over the Northern Hemisphere at horizons ranging from Lower Cretaceous to Senonian and has been found in the Atlantic Coastal Plain in the Raritan and Magothy formations. Abietites longifolius ranges through the Potomac group of Maryland and Virginia and is found in the Raritan formation in New Jersey and in the Fuson formation of the Black Hills. Sapindopsis magnifolia is a Patapsco species, Sterculia towneri (Lesquereux) is found in the
Magothy formation, and Araliopsoides cretacea (Newberry) is found in the Raritan and Magothy formations of the Atlantic Coastal Plain.

A prominent element in the Cheyenne sandstone flora consists of the three nominally distinct species of Sapindopsis, which are equally prominent in the Patapsco formation of Maryland and Virginia. One of these is also probably present in the true (later) Dakota flora, and another has been recorded from the Fuson formation of the Black Hills, although the latter is not entirely characteristic. This considerable Patapsco element in the Cheyenne flora is of considerable interest, for it includes, in addition to the abundant remains of these three species of Sapindopsis, a characteristic Abietites (A. longifolius). These three forms of Sapindopsis are distinguished chiefly by the size of their leaflets and probably in both floras represent slight variants of a single botanic species.

The Patapsco flora has been rather definitely correlated with the Albian stage of Europe. ${ }^{18}$ I do not regard the community of Sapindopsis and Abietites in the Cheyenne and Patapsco as indicating synchroneity, for the following reasons. The Patapsco flora contains 41 species that persist into it from the older Lower Cretaceous. Only one of these, the Abietites, occurs in the Cheyenne, and it is also present in the Atane beds of Greenland and the Raritan formation of New Jersey. The Patapsco flora numbers 83 species, and of this large number only two have been found in the immediately overlying Raritan formation. Neither of these occurs in the Cheyenne.

The Cheyenne entirely lacks the older elements that serve to distinguish the Patapsco from the Raritan and stamp its age as Albian. For example, the following fern genera of the Patapsco are not found in the Cheyenne: Ruffordia, Acrostichopteris, Knowltonella, Cladophlebis, Dryopteris, Onychiopsis, Sagenopteris, Tempskya, Scleropteris, and Thinnfeldia; the following cycadophyte genera of the Patapsco are not found in the Cheyenne: Ctenopteris, Zamiopsis, Nilsonia, Zamites, Dichotozamites, and Podozamites; and the following coniferophyte genera of the Patapsco are not found in the Cheyenne: Nageiopsis, Brachyphyllum, Araucarites, Pinus, Frenelopsis, Sphenolepis,

18 Berry, E. W., Maryland Geol. Survey, Lower Cretaceous, p. 172, 1911. 
and Widdringtonites. The vast majority of these are old genera which became extinct before the dawn of the Upper Cretaceous and which give the Albian facies to the Patapsco. Even as regards the angiosperm element of the Patapsco, which might be expected to show more similarities to only slightly younger formations, the following genera of the $\mathrm{Pa}$ tapsco are not represented in the Cheyenne: Cyperacites, Plantaginopsis, Alesinaphyllum, Populus, Populophyllum, Nelumbites, Menispermites, Celastrophyllum, Cissites, Araliaephyllum, Hederaephyllum, and Aristolochiaephyllum.

The angiosperms of the Cheyenne flora, comprising only eleven species of six genera, contain but two genera that are found in the Albian (Sapindopsis and Sassafras).

Moreover, the Cheyenne flora entirely lacks those supposed Dakota sandstone species which are common in the Woodbine sand of Texas, the Bingen sand of Arkansas, the Tuscaloosa formation of Alabama, and the Raritan, Magothy, and allied formations of the Atlantic coast region and which clearly show that the so-called Dakota flora as it stands in the literature is not a chronologic unit and that there is a Dakota sandstone which is approximately of the same age as these formations and which I am inclined to consider of Turonian age according to European standards.

I regard the Cheyenne flora as clearly of the same general facies as those of the Upper Cretaceous formations that immediately succeeded the Cheyenne sandstone in time and as set apart from any known Lower Cretaceous floras by the absence of the characteristic Lower Cretaceous element in part exemplified by the Patapsco genera of ferns, cycads, and conifers enumerated in a preceding paragraph.

The Cheyenne flora is unquestionably older than the flora of the Woodbine sand of Texas, for although the latter also consists largely of so-called Dakota forms there is not a single species that is common to the Cheyenne and Woodbine, and the "Dakota" species of the Woodbine are nearly all the common forms of Coastal Plain formations of known age. I have recently completed a study of the Woodbine flora, ${ }^{19}$ so that these statements are authoritative.

The range of the plants found in the Cheyenne sandstone is given in the appended table of distribution.

Distribution of flora of Cheyenne sandstone.

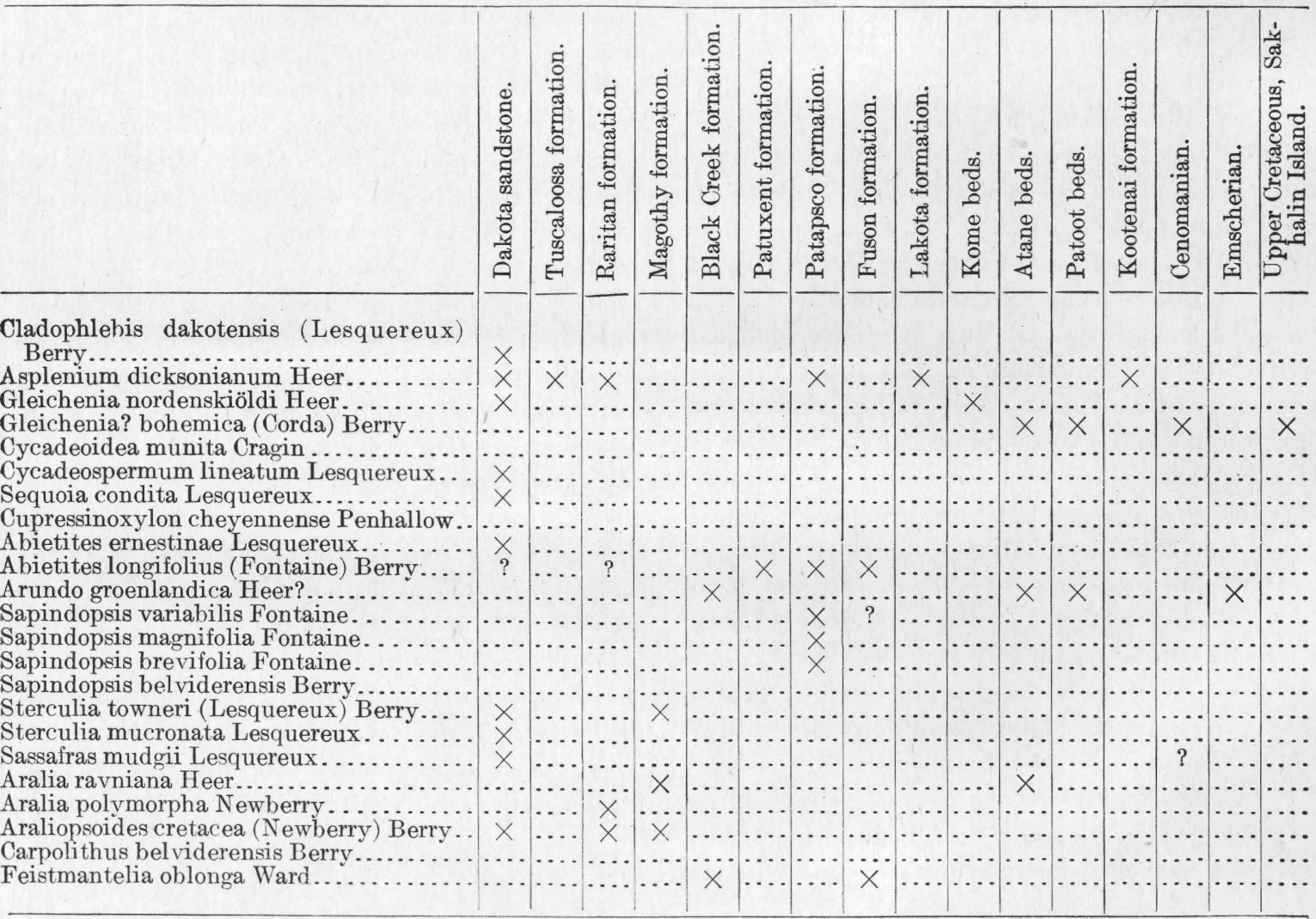

19 Berry, E. W., The flora of the Woodbine sand at Arthurs Bluff, Tex.: U. S. Geol. Survey Prof. Paper 129, pp. 153-181, 1922. 


\section{SYSTEMATIC DESCRIPTIONS.}

Phylum PTERIDOPHYTA.

\section{Class LEPTOSPORANGIATAE.}

Order POLYPODIALES.

Family POLYPODIACEAE.

Genus CLADOPHLEBIS Brongniart.

Cladophlebis dakotensis (Lesquereux) Berry.

Pteris dakotensis Lesquereux, U. S. Geol. Survey Mon. 17 (Flora of the Dakota group), p. 24, pl. 1, figs. 2, 3, 1892.

This species, the type material of which was collected 10 miles northeast of Delphos, Kans., was described as follows by Lesquereux:

Ultimate pinnae linear-lanceolate, pinnately deeply cut into oblique equal subopposite lanceolate bluntpointed and subfalcate pinnules, connate above the base, entire, close but disconnected above; median vein thin, distinct; secondaries opposite, 6-7 pairs, simple, curving upward in passing to the borders.

This form is obviously to be referred to the genus Cladophlebis, which was so abundant during the Mesozoic era. It was referred to Pteris by Lesquereux, as was the habit among earlier paleobotanists. The material which Lesquereux had and that from the Cheyenne sandstone are both too meager for critical comparisons with other described species of Cladophlebis. The two specimens from the Cheyenne sandstone came from Thompson Creek near the Flume, 2 miles northwest of Belvidere (2221).

\section{Genus ASPLENIUM Linné.}

\section{Asplenium dicksonianum Heer.}

Asplenium dicksonianum Heer, Flora fossilis arctica, vol. 3, Abt. 2, p. 31, pl. 1, figs. 1-5, 1874; vol. 6, Abt. 2, pp. 3 , 33, pl. 2, fig. 2 ; pl. 32, figs. $1-8$; 1882.

Dawson, Roy. Soc. Canada Trans., vol, 1, sec. 4, p. 11, 1883 ; vol. 3, sec. 4, p. 5, pl. 3, fig. 1, 1885; Canada Geol. Survey Ann. Rept., new ser., vol. 1, p. 76, 1886; Roy. Soc. Canada Trans., vol. 10, sec. 4, p. 91, 1892.

Lesquereux, The flora of the Dakota group, p. 24, pl. 1, fig. 1, 1892.

Newberry, The flora of the Amboy clays, p. 39, pl. 1, figs. 6,7 ; pl. 2, figs. 1-8; pl. 3, fig. 3, 1896.

Ward, U. S. Geol. Survey Nineteenth Ann. Rept., pt. 2, p. 704, pl. 170, fig. 1, 1899; Jour. Geology, vol. 2, pp. 259, 261, 1894.

Fontaine, in Ward, U. S. Geol. Survey Nineteenth Ann. Rept., pt. 2, p. 664, pl. 162, figs. 6-8, 1899 (not Fontaine, 1888).

Kurtz, Contribuciones á la palaeophytologia argentina, III: Mus. La Plata Rev., vol. 10, p. 49, 1899 [1902].
Berry, Torrey Bot. Club Bull., vol. 38, p. 409, 1911; New Jersey Geol. Survey Bull. 3, p. 68, pl. 5, figs. 3, 4, 1911; Maryland Geol. Survey, Upper Cretaceous, p. 767, 1916; U. S. Geol. Survey Prof. Paper 112 , p. $53,1919$.

This species was described by Heer in 1874 from material found in the Kome beds (Lower Cretaceous) of Greenland. It was subsequently identified by Heer in material from the much later Atane beds (Upper Cretaceous) of Greenland; Dawson reported it from a number of localities in the Kootenai formation (Lower Cretaceous) of British Columbia, although these records are questionable; and Fontaine and Ward described it from specimens obtained in the Lower Cretaceous of the Black Hills. It is also reported by both Lesquereux and Ward from the Dakota sandstone, and by Kurtz from Argentina. It seems very doubtful if these specimens can all be the same plant, and the geologic range alone suggests that the earlier and the later forms may be distinct. The Lower Cretaceous forms certainly suggest a relationship with those widespread types of sterile fronds variously identified as Thyrsopteris or Onychiopsis, and they may be compared with Onychiopsis goepperti (Schenk) Berry. The Upper Cretaceous forms suggest Anemia rather than Asplenium and are much like the widespread Locene species Anemia haydenii (Lesquereux) Cockerell and Anemia subcretacea (Saporta) Gardner and Ettingshausen. However, in the absence of representative material from the different horizons, it seems unwise to attempt any segregation at the present time, and the synonymy is cited in full for the use of some future student who may have access to enough material to enable him to make an accurate revision and segregation of this so-called species. Attention should also be called to its resemblance to the form occurring in the Upper Cretaceous of Greenland, the Raritan formation of New Jersey, and the Tuscaloosa formation of Alabama which goes by the name Dicksonia groenlandica Heer, although the ground for considering it a Dicksonia is entirely inconclusive.

Besides occurring at the localities named above the present species is abundant in the Raritan formation of New Jersey and Maryland, and material that is absolutely identical with the New Jersey Raritan material which I have seen and with that from the Dakota sandstone is present in the Tuscaloosa formation of 
Alabama and the Cheyenne sandstone of southern Kansas. I have recently received a fine specimen from northeastern New Mexico from a sandstone that appears to represent the Purgatoire formation.

The specimens from the Cheyenne sandstone, all of which are fragmentary, were found in brown clay in a draw on Medicine Lodge Creek, 3 miles above Belvidere (collected by Ward and Vaughan, 1896, no number); $1 \frac{1}{2}$ miles northwest of Belvidere (2218); near Medicine Lodge Creek, 2 miles west of Belvidere (2224, same locality as that first cited); and $2 \frac{1}{2}$ miles due west of Belvidere (2226).

\section{Order GLEICHENIALES.}

\section{Family GLEICHENIACEAE.}

Genus GLEICHENIA Smith.

Gleichenia nordenskiöldi Heer. ${ }^{20}$

Plate XLVII, figure 1.

Gleichenia nordenskiöldi Heer, Flora fossilis arctica, vol. 3, Abt. 2, p. 50, pl. 9, figs. 6-12, 1874; vol. 6, Abt. 2, p. 8, pl. 1, figs. 1, 1a, 1882 .

Lesquereux, U. S. Geol. and Geog. Survey Terr. Ann. Rept. for 1874, p. 334, pl. 2, fig. 5, 1876; Cretaceous and Tertiary floras, p. 26, pl. 1, figs. 1, 1a, 1883; U. S. Geol. Survey Mon. 17, p. 25, 1892.

This species was described originally by Heer from material collected in the Kome beds of western Greenland. Species of Gleichenia are very abundant throughout the Cretaceous section of that region, and Heer founded very many species on this material, more than seem warranted. The stratigraphic boundary between the Kome and Atane beds has been shown by subsequent workers to be very indefinite, and the Atane beds are present at the Kome locality, a fact which may account for the range accredited to a large number of the species.

Lesquereux subsequently identified Gleichenia nordenskiöldi from the Dakota sandstone at Fort Harker, Kans. His material was not very convincing and perhaps should not have received a specific name. Material

20 The following do not belong to this species:

Gleichenia nordenskiöldi Fontaine, U. S. Geol. Survey Mon. 15, p. 119, pl. 21, fig. 11, 1890.

Gleichenia nordenskiöldi Fontaine, in Ward,U. S. Geol. Survey Mon. 48, p. 231 , pl. 65, figs. 24-29, 1906 .

Pezopteris strictinervis Fontaine. Fontaine, in Diller and Stanton, Geol. Soc. America Bull, vol. 5, p. 450, 1895; in Stanton, U. S. Geol. Survey Bull. 133, 1895, p. 15, [1896].

Aspidium heterophyllum Fontaine. Fontaine, in Diller and Stanton, op. cit., p. 450 ; in Stanton, op. cit., p. 15.

Osmunda dicksonioides Fontaine. Fontaine, in Diller and Stanton, op. cit., p. 450; in Stanton, op. cit., p. 15. identical with that of Lesquereux is not uncommon in the Cheyenne sandstone, and I have used the same name for it, although it should be borne in mind that neither Lesquereux's material nor mine is distinct from what has commonly been called Gleichenia zippei Heer, ${ }^{21}$ which has been identified, often wrongly, I believe, at a large number of localities and horizons.

The unwarranted determination of unidentifiable scraps by Ward and especially by Fontaine has almost completely obscured the stratigraphic value of any material that they described. The specimen from Dutch Gap, Va., which Fontaine referred to this species not only differs from the type material but might readily represent the terminal portion of half a dozen different Patuxent species of ferns. Similarly the specimens from the Knoxville formation which Fontaine referred to Gleichenia nordenskiöldi are not only not that species but they are not even all the same thing, and the fact that these identical fragments were also referred by Fontaine to Pecopteris, Aspidium, and Osmunda, as well as to Gleichenia is a fitting commentary on both the character of the material and the critical value of Fontaine's results.

What I have called Gleichenia nordenskiöldi is found in the Cheyenne sandstone in clay $2 \frac{1}{2}$ miles due west of Belvidere (2226), also described as a draw on Medicine Lodge Creek, 3 miles above Belvidere (fern bed, no number), collected by Ward and Vaughan in 1896.

\section{Gleichenia? bohemica (Corda) Berry.}

Plate XLVII, figure 2.

Pecopteris bohemica Corda, in Reuss, Versteinerungen der böhmischen Kreideformation, p. 95, pl. 49, fig. 1, 1846.

Heer, Flora fossilis arctica, vol. 3, Abt. 2, p. 96, pl. 26, fig. 17a, 1874; vol. 7, p. 6, pl. 58, fig. 4, 1883.

Engelhardt, Naturf. Gesell. Isis in Dresden Abh., 1891, No. 7, p. 86.

Kryshtofovich, Coll. Sci. Imp. Univ. Tokyo Jour., vol. 40 , art. 8, p. 31, fig. 2, 1918.

This species was described by Corda in $\mathbf{1 8 4 6}$ from material obtained in the Cenomanian of Bohemia. It was subsequently recorded from the same horizon in Saxony. Heer referred a number of Greenland specimens to it, and lately Kryshtofovich has recorded it from the Upper Cretaceous of Sakhalin Island. If these

21 Heer, Oswald, Flora fossilis arctica, vol. 1, p. 79, pl. 43, fig. 4, 1868. 
records all represent the same species, it was evidently a wide-ranging type in the earliest stage of the Upper Cretaceous, which spread from the Arctic region southward into North America, Europe, and Asia. There are five specimens in the Cheyenne sandstone that appear to be identical with Heer's Greenland forms, but as they are preserved in a coarse sandstone their detailed characteristics are obliterated. The pinnules are coriaceous, long, and narrow and somewhat resemble what Heer ${ }^{22}$ called Gleichenia rigida.

Although details of frond habit and fructification are lacking I have ventured to transfer this form from Pecopteris to Gleichenia, as it appears to be congeneric with the numerous Cretaceous forms of that genus.

It was found in the Cheyenne sandstone on the left bank of the middle branch of Champion (Wildcat) Draw, half a mile south of Belvidere (2229).

\section{Phylum CYCADOPHYTA.}

\section{Order CYCADEOIDALES.}

\section{Genus CYCADEOIDEA Buckland.}

Cycadeoidea munita Cragin.

Cycadeoidea munita Cragin, Washburn College Lab. Nat. Hist. Bull., vol. 2, p. 65, 1889.

Ward, U. S. Geol. Survey Nineteenth Ann. Rept., pt. 2, p. 541, 1899.

Hill ${ }^{23}$ states that there is some doubt as to the occurrence of this specimen at this horizon. Lester F. Ward, who subsequently visited the locality, states that he was satisfied that it could not have come from the Cheyenne sandstone but may have weathered out from the overlying "Reeder sandstone." The material, which is only a fragment, has never been studied by a competent person, although Ward states that it is surely a fragment of a cycad trunk.

Whatever its true horizon it is of interest as one of the latest authentic occurrences of this type of plant.

\section{Genus CYCADEOSPERMUM Saporta.}

Cycadeospermum lineatum Lesquereux.

Cycadeopsermum lineatum Lesquereux, U. S. Geol. Survey Mon. 17, p. 30, pl. 1, fig. 14, 1891 [1892].

This seed, which was found 10 miles northeast of Delphos, Kans., was described by Lesquereux as follows:

22 Heer, Oswald, Flora fossilis aretica, vol. 1, p. 80, pl. 44, fig. 1, 1868

23 Hill, R. T., Am. Jour. Sci., 3d ser., vol. 50, p. 212, 1895.
Seed oblong-ovate, slightly falcate, rounded at the lower end, short acuminate at the other; testa smooth, transversely lineate, the lines distant, parallel; carena clearly marked longitudinally on both sides, the inner concave, the outer rounded.

Length 1 to 1.5 centimeters; width about 6 millimeters, somewhat compressed. Testa thick, shining, and ligneous.

Cycadophyte seeds are not so inequilateral, and the present form is probably angiospermous. This genus was proposed for Jurassic forms, of which many have been described. A few have been described from both Lower and Upper Cretaceous material. The Cheyenne form is certainly identical with Lesquereux's type. Whether or not it is congeneric with the other species referred to Cycadeospermum, or whether indeed it represents the seed of a cycadophyte and not an angiosperm, can not be determined. My impression is that it belongs to the latter rather than the former.

Material identical with Lesquereux's type is found in the Cheyenne sandstone $1 \frac{1}{2}$ miles northwest of Belvidere (2218) and near Medicine Lodge Creek, 2 miles west of Belvidere (2224).

\section{Phylum CONIFEROPHYTA.}

Order CONIFERALES.

Family CUPRESSINACEAE.

Genus SEQUOIA Endlicher.

Sequoia condita Lesquereux.

Plate XLVIII, figures 1-11.

Seguoia condita Lesquereux, U. S. Geol. and Geol. Survey Terr. Bull., vol. 1, p. 391, 1875 [1876]; Ann. Rept. for 1874, p. 355, pl. 4, figs. 5-7, [1876]; U. S. Geol. Survey Terr. Rept., vol. 8 (Cretaceous and Tertiary floras), p. 32, pl. 1, figs. 5-7, 1883; in Cook and Smock, Report on clay deposits in New Jersey, p. 29, 1878.

The inextricable confusion that results from the identification of detached fragments of coniferous foliage when they can not be checked by fruits or in some other way is well illustrated by the forms that are variously referred to Glyptostrobus gracillimus Lesquereux, Sequoia gracillima Newberry, Widdringtonites reichii Heer, etc. In volume 6 of the final reports of the United States Geological Survey of the Territories Lesquereux gave figures of a plant which he had named some years earlier Glyptostrobus gracillimus and which he compared with Frenelites reichii of Ettingshausen. When 
Newberry described the flora of the "Amboy clays" (Raritan formation) he renamed Lesquereux's species Sequoia gracillima because he found associated with similar foliar remains in New Jersey elongate cones with scales resembling those of a Sequoia. He commented on the resemblance of these cones to Geinitzia, but the matter rested here until I compared specimens of the so-called Sequoia gracillima cones with those of the European Geinitzia formosa Heer and found the two to be identical. In the European Upper Cretaceous these cones were found attached to foliage of a very different type from Glyptostrobus gracillimus or Sequoia gracillima, although in America the cones were always detached. Foliage like that of Geinitzia formosa was found, however, associated with them. It seemed obvious that the cones referred to Sequoia gracillima were those of Geinitzia formosa, and accordingly I so assigned them. I had collected hundreds of these cones and had abundant comparative material. When I revised the Raritan flora I had much larger collections than those of Newberry, and I found that the foliage which he had called Sequoia gracillima was identical with what he had identified as Widdringtonites reichii (Ettingshausen) Heer.

These remains are abundant in the Atlantic Coastal Plain as far south as Alabama and have never been found with ovulate cones, although the staminate cones are not uncommon. Thus the slender conifer in the East is Widdringtonites. Whether Lesquereux's Glyptostrobus gracillimus also represents this genus or not I do not know. I suspect that in spite of minor and not very obvious differences Glyptostrobus gracillimus is none other than Sequoia condita, which Lesquereux described in Hayden's report for 1874 from very incomplete material collected at Fort Harker and Clay Center, Kans.

The most abundant plants in the Cheyenne sandstone are graceful, delicate coniferous branches bearing numerous distinctive cones identical with the one referred to Sequoia condita by Lesquereux, as is the foliage, which has been recorded in the literature of the Cheyenne sandstone as Glyptostrobus gracillimus (Ward) and Sequoia gracillima. (Knowlton). The collections naturally contain many specimens of detached cones and many specimens of foliage lacking cones, but the evidence is as strong as it can possibly be that when cones and foliage are found in union in a dozen specimens those that are found separated in the same bed are none other. I have specimens of cones from six localities and of the foliage from thirteen localities around Belvidere.

Moreover, the foliage shows considerable variation in the extent to which the leaves are pointed or obtuse, appressed or spreading, depending not only on a natural amount of variation but also on whether it represents shoots of the year or older twigs, and furthermore the appearance differs greatly with the nature of the matrix, the extent to which iron salts have been deposited along the channels formed by the twigs, and other conditions. The specimens found in the sandstones appear different from those found in the clays, and some specimens in the clays which were much incrusted suggested at first sight the genus Brachyphyllum.

Before describing the species as fully as the large collection studied permits, I would like to point out that Sequoia condita is not related to Widdringtonites, Juniperus, Glyptostrobus, or Sphenolepis - genera in which the foliage is comparable - and it is perfectly distinct from Sequoia fastigiata. It is known only from the Cheyenne sandstone and from the true Dakota of Kansas. In the absence of attached cones the foliage might be referred to any one of several genera, or its variants might be referred to several different species in as many genera. Taken together, they demonstrate that it is a Sequoia, and I do not feel the slightest doubt but that all the material from the Cheyenne sandstone represents a single botanic species. It may be described as follows: Twigs rather rigid, pinnately branched, slender elongate; covered with small, decurrent, crowded leaves varying from appressed to spreading falcate, thick and coriaceous, acute or obtusely pointed, slightly keeled but without vein. The leaves are arranged in a spiral phyllotaxy which becomes higher with the elongation of the twigs. In old twigs 2 to 3 millimeters in diameter they are scattered, spreading, and falcate. Their blunt tip is more apparent than real and is due to their usual or partial preservation in the form of casts. The variations in appearance are well shown in the accompanying figures. The cones vary from prolate to nearly spherical in 
form and consist of about 22 .scales spirally arranged, as compared with about 30 in the cones of the modern redwood. The axis is stout and fusiform. The scales have a thin rounded peduncle expanding distad into a rhomboidal peltate tip only slightly wider than high, with a wrinkled marginal face surrounding a central laterally elongated umbilicus. Length of cone (maximum), 2.4 centimeters; diameter (maximum), 1.8 centimeters. Average size somewhat smaller. Length of scale (maximum), 8 millimeters; width, 6.5 millimeters; height, 4.5 millimeters. These cones are remarkably like those of the existing redwood (Sequoia sempervirens) in every respectsize of axis, shape of scales, etc.-except that the scales are less numerous in the fossils and the maximum size of the scales is about sixsevenths that of the average redwood scale. The average size of the fossil cones is from two-thirds to five-sevenths that of the modern cones.

The condition of preservation of these cones is a strong argument in favor of the eolian character of the sandstone. All have the scales somewhat shriveled and widely separated and are exactly comparable to thoroughly dried redwood cones. They are exceedingly abundant in the sandy phases of the Cheyenne sandstone, as if they had been blown about by winds and accumulated in hollows. I have not encountered them in the clays, although the clays contain specimens of the foliage.

Whether or not Sequoia condita occurs at any other horizons or localities is problematic and can be determined only by the best of evidence, for, as I have already stated, the foliage is duplicated more or less closely by a variety of unrelated conifers. In particular the Upper Cretaceous conifer known as Widdringtonites subtilis, a form that I have not mentioned above, has foliage very like the more slender twigs of Sequoia condita, and in the absence of cones I doubt if the two could be distinguished. However, a single specimen of Widdringtonites subtitis found in the Tuscaloosa formation of Alabama had small four-valved cones entirely unlike those of Sequoia condita.

The Cheyenne sandstone localities are as follows: Cones and foliage, black hills near Belvidere (773); $1 \frac{1}{2}$ miles northwest of Belvidere (2218); Champion (Wildcat) Draw, threefourths mile south of Belvidere (2222); near
Medicine Lodge Creek, 2 miles west of Belvidere (2224); left bank of middle branch of Champion (Wildcat) Draw, half a mile south of Belvidere (2224); right bank of same draw (2231); Osage Rock, near Belvidere (7406). Foliage only, Stokes Hill, 100 yards south of National Corral (2219); "Lanphier shales" in Champion (Wildcat) Draw, three-fourths mile south of Belvidere (2223); "Lanphier shales" in a draw 1 mile southwest of Belvidere (2225); hills between Spring Creek and Soldier, 4 miles northeast of Belvidere (2227); Champion (Wildcat) Draw, right (east) branch, half a mile south of Belvidere, in "Lanphier shales" (2228); first draw west of Champion (Wildcat) Draw, half a mile south of Belvidere (2233).

\section{Family ABIETINEACEAE.}

Genus ABIETITES Hisinger.

\section{Abietites longifolius (Fontaine) Berry.}

Plate XLVII, figure 3.

Abietites longifolius (Fontaine) Berry, U. S. Nat. Mus. Proc., vol. 40, p. 315, 1911; Maryland Geol. Survey, Lower Cretaceous, p. 407, pl. 67, fig. 7, 1911.

Leptostrobus longifolius Fontaine, U. S. Geol. Survey Mon. 15, p. 228, pl. 101, fig. 2; pl. 102, figs. 1-4; pl. 103, figs. $6-12$; pl. 104, fig. 6 , 1890; in Ward, U. S. Geol. Survey Nineteenth Ann. Rept., pt. 2, p. 671, pl. 163, fig. 15; pl. 165, fig. 3, 1899; U. S. Geol. Survey Mon. 48, pp. 281, 481, 482, 491, 506, 528, 557, pl. 110, fig. 11, pl. 116, fig. 1, 1906.

Leaves narrow, needlelike, 10 to 15 centimeters in length, aggregated in bundles. Bundles apparently borne on short shoots, with many leaves in each bundle. No satisfactory venation can be made out. Fontaine described a number of veins in these forms, but as nearly as can be determined these are simply folds due to compression or the angles of the leaf.

This species has a considerable geologic as well as geographic range, having been recorded from the Kootenai formation of British Columbia, the Fuson formation of the Black Hills, and the Potomac group in Maryland and Virginia. In the Potomac group it is of frequent occurrence and individually abundant, being found in the oldest as well as the youngest beds, but much more commonly in the latter. The remains are always poorly preserved and were evidently much macerated before fossilization. They are closely comparable with Pinites solmsi Seward, of the Wealden, and with Pinus peterseni Heer, from the Kome 
beds of Greenland. They appear to be identical with specimens from the Atane beds of Greenland which Heer ${ }^{24}$ described as Pinus vaginalis. I have not, however, included the latter in the foregoing synonymy, as it is an earlier name and would involve changing the well-known and highly characteristic name longifotius.

These remains are very common in the Cheyenne sandstone. Similar forms under different specific names are common and wideranging at Lower and Upper Cretaceous horizons in North America, Europe, and Asia.

The Cheyenne sandstone localities are black hills near Belvidere (773); $1 \frac{1}{2}$ miles northwest of Belvidere (2218); Thompson Creek near the flume, 2 miles northwest of Belvidere (2221); Champion (Wildcat) Draw, three-fourths mile south of Belvidere (2222); 1 mile southwest of Belvidere (2225); left bank of middle branch of Champion Draw, half a mile south of Belvidere (2229); and right bank of same branch (2231).

\section{Abietites ernestinae Lesquereux.}

Abietites ernestinae Lesquereux, U. S. Geol. Survey Terr. Rept., vol. 6, p. 49, pl. 1, fig. 7, 1874.

Pterophyllum haydenii Lesquereux (part), Am. Jour. Sci., 2 d ser., vol. 46 , p. 91, 1868.

Lesquereux characterized this species as follows:

Cone oblong, abruptly narrowed to a short pedicel, scales broad, truncate, appressed, and imbricated in spiral.

This diagnosis obviously has nothing that would serve to set it apart from what might be written of dozens of fossil cone fragments of diverse relationships. The species was described from fragments collected near Decatur, Nebr., and similar cone fragments are present in the Cheyenne sandstone. They are not to be distinguished from other so-called species which I have referred to the genus Abietites of Hisinger. ${ }^{25}$

This genus is a convenient and useful repository for fossils, both strobilar or foliar, whose real or fancied affinities are with the modern Abietinaceae. These range in age from the Keuper to the Pliocene, though the bulk came from the Cretaceous, and they comprise obscure impressions of foliage and cones, none of which have any real biologic value or present any

${ }^{24}$ Heer, Oswald, Flora fossilis aretica, vol. 3, Abt. 2, p. 103, pl. 27, fig. $15 \mathrm{~b}, 1874$

25 Hisinger, W., Lethaea suecica, p. 110, 1837. definite clue to their true relationship. Fontaine has included in this genus fossils from the Triassic of North Carolina and various indefinite remains from the Trinity group of Texas, the Shasta series of California, the Lakota sandstone of the Black Hills, and the Potomac group of Maryland and Virginia. The Potomac fossils he segregated into four species, all of which were based on obscure cone impressions and none of which possess much specific value. When it is remembered what diverse appearances may be assumed by a single species of cone, irrespective of individual variation, as a result of different stages of maceration before preservation, of differences in the matrix, and of differences in the direction and force of compression, it seems very probable that such forms can never be discussed satisfactorily.

Similar forms from the English Wealden and later Cretaceous are described by Carruthers, Gardner, Seward, and others and referred to the comprehensive genus Pinites of Endlicher (1847). They are in all probability congeneric if not specifically identical with American forms referred to Abietites, and that name is preferable, as Pinites Endlicher is antedated. by Pinites Witham, which was proposed for very different objects.

Abietites cones are also common in the French and Belgian Cretaceous and have usually been referred to the genus Pinus, although there is slight warrant for such a procedure.

Abietites cones are rare in the Cheyenne sandstone, being known only from Osage Rock, at Belvidere, in the "Stokes sandstone" below the so-called Champion shell bed at the base of the Kiowa shale (2232).

\section{Genus CUPRESSINOXYLON Goeppert.}

\section{Cupressinoxylon cheyennense Penhallow.}

Cupressinoxylon cheyennense Penhallow, Roy. Soc. Canada Trans., 2d ser., vol. 6, sec. 4, p. 76, 1900 [1901]; Manual of North American gymnosperms, p. 238, 1907.

This species was described as coming from the Cheyenne sandstone east of Stokes Hill, on the Kiowa-Baker County line, and was collected by Prosser.

There is nothing to be added to the original description of this species, which was unillustrated. Nor is it worth while to quote that description, for it is very doubtful if the form could be recognized again, even by the author, 
short of comparison with the type sections. There is some doubt as to whether it came from the Cheyenne sandstone. I include it merely for the sake of completeness. In the case of Araucarioxylon prosseri, which Penhallow ${ }^{26}$ recorded from this region, the data are so entirely uncertain that I omit any further reference to it.

Cupressinoxylon cheyennense is of some interest, as Penhallow definitely remarks upon the presence of growth rings, which is thus in accord with my supposition that the region had an arid climate and seasonal rainfall.

\section{Phylum ANGIOSPERMOPHYTA.}

Class MONOCOTYLEDONAE.

Order POALES.

Genus ARUNDio Linné.

\section{Arundo groenlandica Heer?}

Arundo groenlandica Heer, Flora fossilis arctica, vol. 3 . Abt. 2, p. 104, pl. 28, figs. 8-11, 1874; vol. 6, Abt. 2 , p. 57 , pl. 17 , fig. 10,1882 ; vol. 7 , p. 18 , pl. 54 , figs. $1-3,1883$.

Brozzi, Soc. ital. sci. nat. Atti, vol. 31, p. 403, pl. 6, fig. 5, 1888; Soc. geol. ital. Boll., vol. 10, p. 376, pl. 16, fig. 3, 1891.

Berry, U. S. Geol. Survey Prof. Paper 84, p. 28, pl. 4, fig. 7, 1914.

Striated culms and fragments of long, linear pointed leaves, 2 to 3 centimeters in width. Veins numerous, fine, and parallel.

This identification is queried because of the general lack of individuality in remains of this sort. They include the specimens from Belvidere that Ward referred to as bamboo-like stems in his discussion of Feistmantelia.

The species was described by Heer from material found in both the Atane and Patoot beds of western Greenland. It was subsequently recorded by me from the Middendorf arkose member of the Black Creek formation in South Carolina and by Bozzi from the Emscherian of Italy. Little reliance can be placed upon records of remains of this sort, however, which also resemble in a general way the somewhat earlier forms referred by Schenk and others to Eolirion.

The Cheyenne sandstone localities are Champion (Wildcat) Draw, shales three-quarters of a mile south of Belvidere (222); hills between Spring Creek and Soldier, 4 miles northeast of

${ }_{26}$ Penhallow, D. P., Roy. Soc. Canada Trans., 2d ser., vol. 6, sec. 4, p. $77,1901$.
Belvidere (2227); and Champion (Wildcat) Draw, right (east) bank half a mile south of Belvidere ("Lanphier shales," 2228).

\section{Class DICOTYLEDONAE.}

Order SAPINDALES.

Family SAPINDACEAE.

\section{Genus SAPINDOPSIS Fontaine.}

Sapindopsis variabilis Fontaine.

Plate LV, figures 2-4.

Sapindopsis variabilis Fontaine, U. S. Geol. Survey Mon. 15 , p. 298 , pl. 151 , fig. 1 ; pl. 152, figs. 1 , 4; pl. 153 , fig. 3 ; pl. 154, figs. $2-4$; pl. 155, figs. $2-5$, 1890; in Ward, U. S. Geol. Survey Nineteenth Ann. Rept., pt. 2, p. 690 , pl. 169, fig. 9 , 1899; U. S. Geol. Survey Mon. 48, pp. 481, 482, 489, 532, pl. 114, fig. 2, 1906.

Berry, U. S. Nat. Mus. Proc., vol. 38, p. 641, 1910; Maryland Geol. Survey, Lower Cretaceous, p. 469, pls. 83, 84, 85, 1911.

Sapindopsis parvifolia Fontaine, U. S. Geol. Survey Mon. 15, p. 300 , pl. 154, fig. 6, 1890.

Eucalyptus rosilriana Ward, U. S. Geol. Survey Mon. 48, p. 530, pl. 113, figs. 9, 10, 1906.

Ficus myricoides Ward, idem, p. 531, pl. 112, fig. 12, 1906. Rogersia angustifolia Fontaine, in Ward, idem, pp. 491, 510 (not p. 521), 1906.

Leaves odd-pinnate, in some specimens evenpinnate, with three pairs of lateral leaflets, which may be opposite, although usually there is a tendency toward a subopposite arrangement, markedly so in several specimens. Leaflets normally lanceolate, individuals of the same leaf about of a size, usually markedly decurrent, but variable in this respect. The proximal leaflets are always less decurrent than the pair next above, and some even have short petioles. The upper leaflets are remarkably variable; some have an abnormal decurrent wing which joins the inner lamina of the next lower pair of leaflets; in others the rachis entirely lacks a wing. The leaf may be terminated abruptly by a pair of leaflets variously coalesced, or the three apical leaflets may be variously united, their laminae may be almost symmetrical or markedly inequilateral, their margins showing a tendency toward undulation, and rarely a leaflet is divided into a basal and an apical part by a sharp constriction on one side near the middle of the blade. The specimens range in size from the small forms upon which Fontaine founded his species S. parvifolia and which are 1.6 centimeters long and 0.4 centimeter wide to forms which approach $S$. magnifolia in size and are 10 centi- 
meters long and 1.5 centimeters wide. The average dimensions of a large number of specimens, however, are 6 to 7 centimeters long by 1 to 1.3 centimeters wide.

Leaves thick, with smooth surface. Rachis and midrib stout. Venation more prominent than in the other species but still very faint, with the exception of the secondaries, which though fine are more conspicuous than in the other species. Secondaries forming a wide angle with the midrib, nearly straight for twothirds of the distance to the margin, where they bend sharply upward and join the secondary next above by a slightly curved arch. As the secondaries are numerous and almost uniformly spaced the venation resembles that of a Eucalyptus except that the marginal hem is much broader than in that genus. In fact some of the detached leaflets were determined by Ward as forms of Eucalyptus, as also was some of the Virginia material of this species.

This species is exceedingly abundant at many localities in the Patapsco formation in Maryland and Virginia and is by far the most characteristic species of that formation, although it has not been detected at certain other undoubted Patapsco horizons. Not especially characteristic material is abundant along Oak Creek, Wyo., in beds that have been referred to the Fuson formation. This species was also suggested by Cockerell ${ }^{27}$ for some leaves from an unknown geologic horizon in southwestern Colorado. I have since examined this material, which is very inconclusive, in my opinion. Cockerell infers that Sapindopsis may be related to Gnetum, but I cannot see any warrant for such a supposition.

This species is an exceedingly variable form in all its details, and as during maceration the most variable apical portion is the last to be destroyed, this variability is emphasized in fragmentary material such as that usually found. When well preserved it furnishes most striking specimens, as may be seen from the specimens reproduced photographically in Plate LV (figs. 2-4). In life its rigid pinnate leaves and strict appearance must have made it a very striking member of the Cheyenne flora.

The Cheyenne sandstone occurrences of Sapindopsis variabilis are Osage Rock at Bel-

\footnotetext{
97 Cockerell, T. D. A., Washington Acad. Sci. Jour., vol, 6, p. 110, 1916
}

videre $(2217,2232)$; Stokes Hill (2220); Thompson Creek near the flume, 2 miles northwest of Belvidere (2221); Champion (Wildcat) Draw, three-fourths mile south of Belvidere (2222); Champion (Wildcat) Draw, right (east) branch, in "Lanphier shale," hali a mile south of Belvidere $(2224,2228,2231)$; in shale in a draw 1 mile southwest of Belvidere (2225); left bank of middle branch of Champion (Wildcat) Draw (2229); shales in draws north of Belvidere (2230); first draw west of Champion (Wildcat) Draw (2233).

\section{Sapindopsis magnifolia Fontaine.}

Plate LV, figure 5; Plate LVI, Plate LVII, figure 2; Plate LIX, figure 3 .

Sapindopsis magnifolia Fontaine, U. S. Geol. Survey Mon. 15, p. 297, pl. 151, figs. 2, 3; pl. 152, figs. 2, 3; pl. 153 , fig. 2 ; pl. 154, figs. 1, 5; pl. 155, fig. 6, 1890; in Ward, U. S. Geol. Survey Mon. 48, pp. 481, 482, $528,1906$.

Berry, U. S. Nat. Mus. Proc., vol. 38, p. 642, 1910; Maryland Geol. Survey, Lower Cretaceous, p. 471, pl. 86 ; pl. 87, fig. 1 ; pl. 88, 1911.

Araha dubia Fontaine, U. S. Geol. Survey Mon. 15, p. 314 , pl. 157, figs. 1, 7, 1890 .

Sapindopsis obtusidolia Fontaine, idem, p. 301, pl. 156, fig. 13 ; pl. 159, figs. 3-6.

Ficophyllum eucalyptoides Fontaine, idem, p. 294, pl. 164, figs. 1, 2; in Ward, U. S. Geol. Survey Mon. 48, p. $489,1906$.

Sapindopsis tenuinervis Fontaine, U. S. Geol. Survey Mon. 15, p. 301, pl. 153, fig. 1, 1890; in Ward, U. S. Geol. Survey Mon. 48, pp. 489, 528, 1906.

Rhus uddeni Lesquereux, U. S. Geol. Survey Mon. 17 (Flora of the Dakota group), p. 154, pl. 57, fig. 2, 1892.

Knowlton, in Hill, Am. Jour. Sci., 3d ser., vol. 50, p. 213, 1895.

Leaves commonly odd-pinnate, although a few even-pinnate forms occur, of considerable size but somewhat variable. Leaflets three pairs, comparatively large, lanceolate, tapering almost equally toward apex and base, the base inequilateral except in terminal leaflets, pointed, often lacking apical portions, length increasing proximad, averaging about 10 centimeters, longest seen 14 centimeters (estimated), shortest 5 centimeters, width varying from 1.1 to 3.2 centimeters, inequilateral, as the outer half of the lamina is broader than the inner half and is markedly decurrent. This feature is least emphasized in the basal leaves, which may even have a considerable petiole, but becomes increasingly pronounced distad, the terminal leaflets often forming a bilobate or trilobate 
whole with the outer margins broadhy decurrent and joining the lamina of the leaflet next below at the point of junction of its inner margin with the rachis. Certain specimens show all the leaflets petiolate, a feature largely emphasized in a specimen from Stump Neck, Md., figured by me in 1911, showing three terminal leaflets with petioles 3 to 4 centimeters in length.

The leaflets in this species are much more commonly petiolate and lacking in the winged rachis than those in $S$. variabilis, in this particular closely resembling the leaflets of the modern Matayba apetala, in which the rachial wings are vestigial. Leaf substance thick and leathery; epidermis firm and glossy. Leaflets commonly subopposite, often markedly so, forming an acute angle with the rachis. Midribs stout and prominent below. Secondaries slender, seen only on the under surface of the leaflets and even there made out with difficulty, eight to ten pairs, branching from the midrib at a rather wide angle, especially in the central part of the leaf; the angle is more acute basally, curving upward ultimately to join a short branch of the secondary next above. Tertiaries fine, forming lax subrhombic areolae where visible.

This species is very common at certain localities in the Patapsco formation of Maryland and Virginia, although at other outcrops of this same formation it has not been detected.

The grounds for the separation of this species from $S$. variabilis are slight, as both are variable and the larger forms of $S$. variabilis are quite as large as the smaller forms of $S$. magnifolia. In the Patapsco formation the two species are found in association at all the localities where either occurs, and the smaller species is usually the more common, as if the larger species represented its occasional more robust forms. On the other hand, S. magnifolia has not been detected in the abundant remains referred to $S$. variabitis found at Oak Creek, Wyo., and there is commonly considerable disparity in size between the two. There are certain other differences which appear to be constant. These are the thicker, relatively longer leaflets of S. magnifolia, with less numerous and somewhat more ascending secondaries, which are not connected distad by relatively flat arches.

The form recorded from the Cheyenne sandstone as Rhus uddeni Lesquereux belongs to this species, and I am convinced that this is true of Lesquereux's type material recorded from the Dakota sandstone and collected, according to J. A. Udden, "from the west slope of the Smoky Hill Buttes near Salemburg post office, Saline County, Kans." There are a number of other species described by Lesquereux in the "Flora of the Dakota group" which, although I do not feel justified in transferring them to Sapindopsis, are open to more or less suspicion. These are Aralia masoni Lesquereux ${ }^{28}$ collected 10 miles northeast of Delphos, Kans., which might represent the terminal part of a Sapindopsis leaf; Laurus angusta Heer, ${ }^{29}$ which is a fragment from Ellsworth County, Kans., that in both form and venation agrees with Sapindopsis; Leguminosites hymenophyllus Lesquereux ${ }^{30}$ which is somewhat less similar to the known species of Sapindopsis; Sapindus diversifolius Lesquereux ${ }^{31}$ from Ellsworth County, Kans., which is also less similar to the known species of Sapindopsis; and Rhus powelliana Lesquereux, ${ }^{32}$ obtained near Fort Harker, Kans., which differs from Sapindopsis in the subordinate lobing and small leaflets developed at the base of the proximal lateral leaflets, in these features resembling Rhus, but which is sufficiently like Sapindopsis to be open to more or less suspicion.

This species has been found in the Cheyenne sandstone at the black hills near Belvidere (773); Osage Rock, Belvidere (2217, 2232, 7406); Stokes Hill 100 yards south of National Corral (2219); Stokes Hill (2220); Thompson Creek near the flume, 2 miles northwest of Belvidere (2221); near Medicine Lodge Creek, 2 miles west of Belvidere (2224); left bank of middle branch of Champion (Wildcat) Draw, half a mile south of Belvidere (2229); shale along right branch of Champion (Wildcat) Draw (2228); and right bank of middle branch of Champion (Wildcat) Draw (2231).

\footnotetext{
28 Lesquereux, Leo, U. S. Geol. Survey Mon. 17, p. 133, pl.15, fig. 4, 1892.

29 Idem, p. 93, pl. 16, fig. 7.

${ }^{30}$ Idem, p. 152 , pl. 55 , figs. $7-9$.

31 Idem, p. 158, pl. 64, fig. 18.

${ }^{32}$ Idem, p. 155 , pl. 56 , figs. 4,5 .
} 
Sapindopsis brevifolia Fontaine.

Plate LV, figure 1; Plate LIX, figure 1.

Sapindopsis brevifolia Fontaine, U. S. Geol. Survey Mon. 15 , p. 300 , pl. 153 , fig. 4 ; pl. 155 , figs. 1 , 7 ; pl. 163, fig. 3, 1890; in Ward, U. S. Geol. Survey Mon. 48, pp. 481, 482, 528, 1906.

Berry, U. S. Nat. Mus. Proc., vol. 38, p. 644; Maryland Geol. Survey, Lower Cretaceous, p. 473, pl. 87, figs. 2-5, 1911.

Leaves odd-pinnate, the terminal leaflet considerably larger than the lateral leaflets, of which but two pairs are known. These are opposite. Leaflets somewhat crowded so that their margins often overlap, with subacute tips, varying in length from 2 to 5 centimeters and in width from 0.8 to 1.6 centimeters, averaging about 3 centimeterslong by 1.3 centimeters wide. Inequilateral toward the base and showing considerable variation in decurrence, even among the few specimens known; in some the rachis is conspicuously winged; in others the leaflets are all petioled, the whole having the aspect of some member of the Leguminoseae. Midribs stout; secondaries ascending, camptodrome, seen with difficulty, as the leaf texture is coriaceous.

This is a poorly marked species of infrequent occurrence at the same localities where the other species of this genus occur and may simply represent a variant of $S$. variabilis; in fact, there is no reason for considering it to represent a distinct botanic species, and the name is retained temporarily simply as a geologic convenience, to be eventually dropped entirely.

The Cheyenne sandstone localities are $1 \frac{1}{2}$ miles northwest of Belvidere (2218), Thompson Creek near the flume, 2 miles northwest of Belvidere (2221); near Medicine Lodge Creek, 2 miles west of Belvidere (2224); left bank of middle branch of Champion (Wildcat) Draw half a mile south of Belvidere (2229); Osage Rock, Belvidere (2232).

Sapindopsis belviderensis Berry, n. sp.

Plates XLIX-LIV.

Leaves of variable size, pinnately compound, ranging in length (in the collected material) from 8 to 19 centimeters and in maximum width from 4.5 to 14 centimeters. These leaves are prevailingly odd-pinnate, but a few are even-pinnate. In addition to the odd terminal leaflet generally present there are invariably three pairs of lateral leaflets, which are generally opposite but sometimes subopposite. These usually decrease regularly in size from the distal to the proximal pair. In some specimens the terminal leaflet is equilateral, but all the other leaflets are inequilateral, often markedly so. All except the terminal leaflet are invariably sessile, the latter being separated from the distal laterals in some of the larger leaves by a considerable interval of rachis. Generally, however, the terminal and upper laterals are confluent in the rachial region to form what, if it were broken away from the balance of the leaf, would be considered to represent a palmately trilobate leaf such as is commonly referred to the genus Aralia. The sinuses may be rather broad, narrowly rounded, or pointed. The leaflets vary greatly in size, shape, and marginal characters but agree in being obtuse, generally abruptly and almost truncately mucronate pointed. The leaflets range in form from narrowly spatulate to broadly ovate or obovate. The margins are invariably toothed, but there is great variation in the amount and degree to which the teeth are developed. Proximally the margins are entire for a greater or less distance. Above this entire portion the teeth, which are remote and rather evenly spaced, may be small and serrate or very prominent and dentate. Were not all sorts of gradations present one might well doubt that they pertained to the same plants. The accompanying illustrations show these variations much better than they can be described. The lateral proximal margins of the terminal pair of leaflets, except in a single specimen, are decurrent on the rachis, extending downward to the point of insertion of the next lower pair of leaflets and often continuous with the distal margins of these. This rachial wing may be broad and triangular, a form which, as the terminal leaflets are the largest, gives the leaf a curious unsymmetrical or artificial appearance. In other specimens the wings are narrow and become reduced to mere marginal hems. In the middle pair of lateral leaflets the proximal margins are only slightly if at all decurrent, and generally they are not decurrent. No decurrence has been o.bserved in the lower lateral leaflets, but they as well as the middle pair have the proximal side of the base fuller than the distal side, the former being generally rounded and the latter 
incurved and sometimes disappearing some distance above the point of insertion. To judge by the lack of petiolules and the generally complete character of the material it does not appear that the leaflets were normally shed, and this is also indicated by the concrescence of the terminal leaflets. The leaves are coriaceous and appear to have been stiff and strict in habit. The rachis is stout and expanded proximad. The midribs are excessively stout and prominent on the lower surface. The secondaries are relatively thin, straight, and subparallel. They vary from camptodrome to craspedodrome. In the entire basal part of the leaf and sometimes in the apex they are camptodrome. In many specimens one secondary runs to each marginal tooth, although in other specimens the camptodrome habit is retained and a short branch enters the marginal tooth. All these features are indicated in the accompanying figures. The tertiary venation is usually obsolete, as the matrix is prevailingly coarse. Occasionally percurrent nervilles are seen. In specimens with broadly winged stripe the venation of the leaf is continued in these wings.

This handsome species is represented by a large amount of material, which is fortunate, as it would be almost impossible to correlate fragmentary material. It is clearly a representative of the genus Sapindopsis and would well merit the specific name of variabilis had that not already been used for the type of the genus, which came from the Patapsco formation of Maryland and Virginia.

In the Patapsco formation the genus Sapindopsis may be totally absent from a locality or present in the greatest abundance, and this is equally true of the Cheyenne sandstone of Kansas, indicating possibly a gregarious habit.

Various species of existing Sapindaceae show similarities to the present species in frm, venation, and variation. All the previously described species of Sapindopsis had entire margins, and no trace of toothed margins has been found in the material from the Atlantic Coastal Plain. The existing genus Matayba Aublet, with which I originally compared Sapindopsis, has leaves with both entire and dentate margins, and the general features of Sapindopsis are shared by other tropical American genera of Sapindaceae. The genus Matayba comprises about two score existing $32333^{\circ}-22-17$ species and is closely related to Cupania, also exclusively American in the existing florain fact, all the genera of the tribe Cupanieae lomatorrhizae as segregated by Radlkofer are confined to the warmer regions of the Western Hemisphere.

Occurrence: Localities 2221, 2224, 2229, 2230, 7406, Medicine Lodge Creek, in draw 3 miles above Belvidere (Cheyenne sandstone No. 3 of Hill); collected by Ward and Vaughan, October 18, 1896 (unnumbered).

Order MALVALES.

\section{Family STERCULIACEAE.}

Genus STERCULIA Linné.

Sterculia towneri (Lesquereux) Berry.

Plate LVII, figure 1; Plate LX; Plate LXI, figure 1.

Aralia towneri Lesquereux, U. S. Geol. and Geog. Survey Terr. Bull., vol. 1, p. 394, 1875 [1876]; Ann. Rept. for 1874, p. 349, pl. 4, fig. 1, 1876; Cretaceous and Tertiary floras, p. 62 , pl. 6, fig. 4, 1883; Flora of the Dakota group, p. 132, pl. 23, figs. 3 , 4; pl. 31, fig. 1, 1892.

Sterculia drakei Cummings, Texas Geol. Survey Third Ann. Rept., p. 210, fig. 8, 1892.

Knowlton, in Hill, Am. Jour. Sci., 4th ser., vol. 1, p. $213,1895$.

Sterculia snowii Lesquereux, Flora of the Dakota group, p. 183 , pl. 30 , fig. 5 ; pl. 31, figs. 2 , 3; pl. 32 , figs. $1-4$, 1892.

Hollick, U. S. Geol. Survey Mon. 50, p. 94, pl. 34, fig. 20, 1907.

Aralia towneri Hollick, New York Acad. Sci. Trans., vol. 16, p. 132, pl. 14, figs. 11, 12, 1897.

Berry, New York Bot. Garden Bull., vol. 3, p. 92, 1903.

I have long thought that the Aralia towneri and Sterculia snowii of Lesquereux represented a single species but have never had a chance to test this belief until I received the present collections from the Cheyenne sandstone, in which this is one of the most abundant forms. It shows considerable variation in size but obviously represents a single botanic species. Unfortunately the name towneri antedates snowii by some 15 years, so that the latter, which is much the better known of the two, becomes a synonym.

From the large amount of material now available the species may be described as follows:

Leaves of variable and often very large size, palmately two to seven lobed. The lobes are prevailingly conical and acuminate, occa- 
sionally widening somewhat medianly and less acutely pointed, separated by generally open and rounded sinuses extending about halfway to the base. The angles that the lobes form with one another and the form of the sinuses vary with the number of lobes, as does also the character of the base, which ranges from truncate to decurrent. The median lobe is generally slightly wider than the others but may be smaller. The normal form is five lobed like the smaller of the two specimens from the Cheyenne sandstone here figured. The texture is so coriaceous that these leaves are well preserved in the scarcely consolidated wind-blown sand of the Cheyenne. The margins are entire. Length from 8 to 20 centimeters; maximum width from 6 to 24 centimeters. Petiole stout, usually broken away, 12 centimeters long in a medium-sized leaf figured by Lesquereux. Midrib stout, channeled, prominent on the under side of the leaf. An equally stout lateral primary diverges from the midrib, usually at its extreme base but occasionally slightly above. In the five-lobed forms this primary forks almost immediately into two subequal branches, which form the midveins of the respective lobes. In specimens having more than five lobes the additional ones are subordinate to the basal laterals, their midveins diverge at an acute angle from the midveins of these laterals, and their separating sinuses are less deep. The secondaries are thin and immersed in the leaf substance and are largely obsolete in the Cheyenne sandstone specimens; they are numerous, regularly spaced, subparalleled, and camptodrome in the lobes and in curved anastomosing loops in the body of the lamina.

This is an exceedingly well marked species and, like most Sterculias, both ancient and modern, shows the characteristic variability of the genus. It was described originally from material collected in the Dakota sandstone of Kansas and occurs in the Big Tucumcari Mountains of New Mexico in beds referred to the Dakota. It is recorded from the Magothy formation of Massachusetts and New Jersey. In the Cheyenne sandstone of Kansas it occurs at these localities: Black hills near Belvidere (773); Osage Rock, Belvidere (2217); Stokes
Hill, 100 yards south of the National Corral (2219); Thompson Creek near the flume, 2 miles northwest of Belvidere (2221); near Medicine Lodge Creek, 2 miles west of Belvidere (2224); left bank of middle branch of Champion (Wildcat) Draw, half a mile south of Belvidere (2229); draws north of Belvidere, in "Lanphier shales" (2230); Osage Rock, in "Stokes sandstone" (2232); Wildcat Draw (7405).

\section{Sterculia mucronata Lesquereux.}

Sterculia mucronata Lesquereux, U. S. Geol. Survey Mon. 17 (Flora of the Dakota group), p. 182, pl. 30, figs. $1-4,1892$.

Leaves coriaceous, prevailingly small, palmately three to five lobed. Lobes entire, conical, separated by open rounded sinuses extending a variable distance, sometimes over halfway to the cuneate or truncate base. Petiole long and stout. Primaries three from the top of the petiole, stout and prominent. In the fivelobed forms subordinate branches from the lateral primaries furnish these with midveins. Secondaries thin, camptodrone. The tips of the lobes are prominently mucronate, and this feature, which suggested the specific name, is especially obvious in the Cheyenne sandstone specimens, where the mucros are 2 millimeters long and perhaps merit the designation cuspidate rather than mucronate.

The fact that these leaves are prevailingly small suggests that they probably represent small leaves of the associated Sterculia towneri, with which they agree in their main featuresthe mucronate tips of $S$. mucronata being the principal differential characteristic. The leaves originally described were obtained from the Dakota of Ellsworth County, Kans., and the species is known only from that region and the Cheyenne sandstone of southern Kansas, although there is a similar but distinct species, Sterculia minima Berry, ${ }^{33}$ in the Magothy formation of New Jersey and Maryland. Two specimens were found in the Cheyenne sandstone near Medicine Lodge River, 2 miles west of Belvidere (2224).

${ }^{33}$ Berry, E. W., Maryland Geol. Survey, Upper Cretaceous, p. 857, pl. 80 , figs. $1-3,1916$. 


\section{Order THYMELEALES.}

\section{Family LAURACEAE.}

Genus SASSAFRAS Linné.

Sassafras mudgii Lesquereux.

Plate LXI, figure 3.

Sassafras mudgii Lesquereux, Am. Jour. Sci., 2d ser., vol. 46, p. 99, 1868; U. S. Geol. Survey Terr. Rept., vol. 6 (Cretaceous flora), p. 78, pl. 14, figs. 3,4 ; pl. 30 , fig. 7,1874 .

Ward, U. S. Geol. Survey Nineteenth Ann. Rept., pt. 2, p. 705 , pl. 170, figs. 4, 5; pl. 171, fig. 1, 1899.

Berry, Bot. Gaz., vol. 34, p. 437, 1902.

?Kurtz, Mus. La Plata Rev., vol. 10, p. 53, 1902.

According to Newberry, this is merely a variety of his Sassafras cretaceum, but I fail to see any ground for this association except that it resembles somewhat the narrower-lobed leaves ascribed to that species. It is somewhat intermediate between these forms and the more typical Sassafras acutilobum but is much more like the modern leaf than either. Lesquereux's figures 3 and 4 of Plate XIV of the "Cretaceous flora" I consider to represent typical forms of this species. In the lengthening of the terminal lobe it approaches the modern Sassafras; and it shows no venation characters which are unlike the modern leaf, for although no marginal veins are discernible, they might have been present in the specimen illustrated in Lesquereux's figure 3, as they are in the identical form from the Cheyenne sandstone figured on the accompanying plate, and both specimens approach Sassafras in the relations of their secondary members in this region. If it is certain that the fruit has been found in the same strata, as Lesquereux ${ }^{34}$ asserts, it only serves to substantiate the impression otherwise obtained that they are true Sassafras leaves. The lateral margins of both the base and the lobes are straighter and more ascending than in the existing Sassafras, and the margin shows a tendency to become wavy. Lesquereux's other figured specimen referred to this species differs in the size and direction of the lateral lobes, in the subbasal primaries, and in the acute tip; the venation also is somewhat dissimilar, the ascending margins bulge outward, and the base is not decurrent on the petiole, as it is most markedly in the specimens shown in his figures 3 and 4 . It resembles somewhat the forms which New-

\footnotetext{
34 Lesquereux, Leo, Flora of the Dakota group, p. 230, 1891 [1892].
}

berry refers to Sassafras acutilobum. Ward's fragmentary leaves from the Black Hills are of doubtful identity. The more perfect specimen that he originally referred to Lindera venusta Lesquereux, which it resembles in outline, is a smaller leaf than $S$. mudgii, with subbasal primaries, considerable breadth of blade, and reduced terminal lobe.

Sassafras mudgii was based on material collected from the hills along Saline River in central Kansas. Up to the present time it has never been found elsewhere, except for the above-mentioned doubtful record by Ward from the supposed Dakota sandstone at Evans quarry, in South Dakota, and a still more doubtful South American record by Kurtz that may well be entirely ignored. It may be that the type was from the Mentor formation of central Kansas rather than from the true Dakota sandstone, as the species has never been found in collections from the Upper Cretaceous of the Atlantic Coastal Plain, but no outcrops of the Mentor formation are known as far north as Saline River.

The Cheyenne sandstone occurrences are Stokes Hill (2220) and near Medicine Lodge Creek, 2 miles west of Belvidere (2224).

\section{Order UMBELLALES.}

\section{Family ARALIACEAE.}

Genus ARALIA Linné.

Aralia ravniana Heer.

Plate LVIII; Plate LIX, figure 4.

Aralia ravniana Heer, Flora fossilis arctica, vol. 6, Abt. 2, p. 84, pl. 38, figs. 1,2, 1882.

Berry, New York Bot. Garden Bull., vol. 3, p. 92, pl. 46 , fig. 7 ; pl. 53 , fig. 2 ; pl. 57 , fig. 1 , 1903; Torrey Bot. Club Bull., vol, 31 , p. 79 , 1904; vol. 37 , p. 27 , 1910; Maryland Geol. Survey, Upper Cretaceous, p. 876, pl. 82, fig. 4; pl. 83, figs. 1-4, 1916.

Aralia groenlandica Heer, idem, pl. 46, fig. 17.

? Sterculia snowii Hollick, New York Acad. Sci. Annals, vol. 11, p. 422, pl. 37, fig. 4, 1898.

This species was described by Heer from material collected in the Greenland Upper Cretaceous (Atane beds) and has been found by me in the Magothy formation of both New Jersey and Maryland. The fragments from Marthas Vineyard, Mass., and Tottenville, N. Y., identified as this species by Hollick, ${ }^{35}$ are not this species, in my judgment. There is a

${ }^{35}$ Hollick, Arthur, U. S. Geol. Survey Mon. 50, p. 99, pl. 37, figs. 1, 2, 1907. 
great display of Aralia-like forms in the middle Cretaceous both of this country and of Europe, and these forms are especially abundant in the Dakota sandstone of the West. Comparisons with existing plants are not so satisfactory, although many tropical Araliaceae show suggestive resemblance. The Moraceae in the genus Artocarpus and its allies also show many similar features.

This most striking species of Aralia, because of its large size, has always been found in a fragmentary condition. Specimens showing all parts of the leaf have now been collected both from Maryland and from Kansas, and these conclusively confirm the restoration of this leaf made by me in 1903 . They also confirm the supposition based on the venation of the New Jersey material, that instead of a broadly ovate median lobe, as Heer supposed, this middle lobe was sublobate by the greater or less development of a lateral lobe on each side, as shown in the accompanying illustrations. The species may be more fully defined in the light of all the material as follows: Leaves large, ranging from 16 to 21 centimeters in length and from 19 to 23 centimeters in maximum width, orbicular in general outline, deeply pinnatelobate. Apex of the terminal and lateral lobes bluntly pointed. Base broadly cuneate. Margins entire. Texture subcoriaceous. Lobes usually seven, separated by relatively narrow ultimately rounded sinuses, comprising an ovate medium terminal lobe and two main lateral lobes on each side, the lower pair being more or less divided. In the Maryland material the auxiliary lobe on the lower side of each main lateral lobe is feebly developed. In the Greenland material it is at least half as large as the main lobe, and the separating sinus extends halfway to the base. Petiole stout, its full length unknown. Midrib very stout and prominent, straight. Lateral primaries two on each side, stout and prominent, the lower pair subopposite and suprabasilar, the upper pair in some specimens subopposite, more commonly separated by a wide interval. The lower primary may fork a short distance above its base, as it does in the Greenland material at an interval of only about 1 centimeter, or this fork may be at least 4 centimeters above the base, as in the Maryland material, the distance depending on the extent to which the auxiliary lobe is developed. The angle of divergence of the primaries from the midrib is about $40^{\circ}$ but varies from specimen to specimen; the basal pair is in general somewhat more divergent than the upper pair. The secondary and tertiary venation is usually obsolete. Some specimens show a few thin remote secondaries diverging from the primaries at angles of about $45^{\circ}$ and sweeping upward in ascending camptodrome curves.

The Cheyenne sandstone material is not abundant. It comes from the left bank of the middle branch of Champion (Wildcat) Draw, half a mile south of Belvidere (2229) and the right bank of the same branch (2231).

\section{Aralia newberryi Berry.}

Aralia newberryi Berry, Torrey Bot. Club Bull., vol. 34, p. 201, pl. 15, fig. 1, 1907; New Jersey Geol. Survey Bull. 3, p. 197, 1911.

Aralia palmata Newberry, Flora of the Amboy clays, p. 117, pl. 39, figs. 6, 7; pl. 40, fig. 3, 1896 (not Lamarck).

Berry, New York Bot. Garden Bull., vol. 3, p. 93, pl. 44, 1903; Torrey Bot. Club Bull., vol. 31, p. 79, pl. 4, fig. 12, 1904.

Aralia rotundiloba Hollick, New York Acad. Sci. Annals, vol. 11, p. 421, pl. 38, fig. 2, 1898.

Aralia polymorpha Newberry, Flora of the Amboy clays, p. 118, pl. 39, figs. 1-5, 1896.

Aralia sp. Hollick, New York State Mus. Ann. Rept., vol. 55 , p. $155,1903$.

Leaves very variable in size and outline, palmately three to five lobed. Lobes conical, obtusely rounded. Sinuses open, shallow, rounded. Margins entire, somewhat undulate basally. Petiole long and stout. Midrib stout, more or less curved or flexuous. Primaries three to five, from the base, prominent, running to the tips of the lobes. Secondaries very slender, camptodrome. The middle lobe is usually longest and broadest, and the basal lateral lobes may be reduced to subordinate and but slightly marked parts of the main lateral lobes.

The relative development of the apical or basal lobes and the depth of the intervening sinuses greatly alter the appearance of these leaves. Some are symmetrical and others decidedly unsymmetrical; some are preeminently three lobed and sublobate and others are five lobed with additional incipient lobes. The variations are almost exactly comparable with the similar variations in the leaves of the modern Sassafras, Sterculia, and Araliaceae.

There seems to be no basis for maintaining the distinctions between the forms united in 
the foregoing synonymy. The Cheyenne sandstone material is more like the irregular $A$. polymorpha than the more symmetrical $A$. palmata of Newberry's original material.

The species is common in the Raritan formation of New Jersey and survives in the overlying Magothy formation. In the Cheyenne sandstone it is represented by three specimens obtained near Medicine Lodge Creek, 2 miles west of Belvidere (2224).

\section{Genus ARALIOPSOIDES Berry.}

Araliopsoides cretacea (Newberry) Berry.

Plate LXI, figure 2.

Araliopsoides cretacea (Newberry) Berry, Maryland Geol. Survey, Upper Cretaceous, p. 879, pl. 74, fig. $3 ; \mathrm{pl}$. 84, figs. 1, 2; pl. 85, figs. 1-5; pl. 88, figs. 1-3, 1916; Torrey Bot. Club Bull., vol. 38, p. 413, 1911.

Sassafras (Araliopsis) cretaceum New,berry, New York Lyc. Nat. Hist. Annals, vol. 9, p. 14, 1868.

[Lesquereux], U. S. Geol. and Geog. Survey Terr., Illustrations of Cretaceous and Tertiary plants, $\mathrm{pl}$. 6, figs. 1-4; U. S. Geol. Survey Terr. Rept., vol. 6 (Cretaceous flora), p. 80, pl. 11, figs. 1, 2; pl. 12, fig 2, 1874; U. S. Geol. Survey Mon. 17, p. 102, 1892.

Newberry, U. S. Geol. Survey Mon. 35, p. 98, pl. 6, figs. 1-4; pl. 7, figs. 1-3; pl. 8, figs. 1, 2, 1898.

?Hollick, U. S. Geol. Survey Mon. 50, p. 77, pl. 30, fig. 10. 1906.

Penhallow, Roy. Soc. Canada Trans., 3d ser., vol. 1, sec. 4 , p. $310,1907$.

Berry, Torrey Bot. Club Bull., vol. 37, p. 22, 1910.

Leaves petiolate, decurrent at base, very smooth above, strongly nerved below, three lobed; lobes entire and acute. The nervation is all strongly defined; the central nerve straight or nearly so; the lateral primary nerve springing from it at an angle of $30^{\circ}$; secondary nerves regularly arched till they approach the margin of the lobes, when they are abruptly curved and run together. From these the tertiary nerves are given off at a right angle, and from these the quaternary nerves spring at a similar angle, together forming a network of which the areoles are subquadrate.-Newberry, 1868.

Newberry includes under Sassafras cretaceum the various forms described by Lesquereux as S. mudgii, S. subintegrifolium, S. integrifolium, S. obtusum, S. cretaceum dentatum, S. cretaceum obtusum, S. acutilobum, Cissites harkianus, and C. salisburiaefolius. Although this list shows the undoubted composite nature of S. cretaceum, it also shows that the extremes of leaf form above mentioned are so closely connected with the more typical leaf by a series of intermediate forms that the problem of where one species shall end and another begin is an extremely difficult one to solve.
I consider the leaf figured by Newberry on Plate VI, figure 1, of "Later extinct floras" (Mon. 35) to be the typical form of this species, thus agreeing with Newberry's original description and with his later opinion expressed in 1898. This type bears considerable resemblance to some modern Sassafras leaves. A slight widening of the terminal lobe of some of these in the basal region would give a leaf strikingly like Araliopsoides cretacea; or were the sinuses of the latter slightly deeper we would have the typical modern leaf. In its basal portion the leaf is like Sassafras, and the indications point to a similar venation in this region. The first pair of secondaries do not branch to form margins of the sinuses; the left one runs directly to the sinus, however, and may possibly have conformed to the margin and been effaced in the specimen; the right one is stronger and runs almost to the sinus, where it makes a sharp turn upward, continuing until it joins the next secondary. This feature is analogous to those in the modern leaf, which may indicate the mode of origin of this peculiar character. This leaf seems to form a central figure from which a series of forms grade in several directions, culminating in quite dissimilar leaves. Lesquereux's Sassafras cretaceum is a more planatoid leaf, with more acute tips, a tendency to become dentate, and the primaries inserted nearer the base. Closely allied to S. cretaceum is his Sassafras (Aratiopsis) mirabile, which serves as a connecting link with his Platanus recurvata. From the Sassafras cretaceum of Lesquereux it is but a step to such a leaf as the one shown on Plate VIII, figure 2, of "Later extinct floras" and to the trilobed forms referred to Cissites harkerianus, and these in turn grade into the more cissoid forms of this species, such as those shown on Plate II, figure 3, of Lesquereux's "Cretaceous flora." The primaries are basal and of not much greater caliber than the regularly succeeding straight secondaries. It is but a step from this leaf to Cissites heerii, on the one hand, with its palmately five-pointed blade, and to such forms as Cissites acuminatus (Pl. V, fig. 4, "Cretaceous and Tertiary floras"), on the other; which in turn, by the elimination of the decreasing dentate points, gives us the leaf shown on Plate V, figure 3, "Cretaceous and Tertiary floras." In the second series of 
leaves diverging from the typical Sassafras cretaceum, the form shown in Plate VIII, figure 1, of "Later extinct floras" is removed a slight distance by the shortening of the blade, the thickening of the primaries and secondaries, and the shortening and rounding of the lobes (Sassafras obtusum); while a smaller leaf would be its logical descendant; and from theseleaves to those referred to the typical Cissites salisburiaefolius is but a step. In the third series of leaves diverging from the typical Sassafras cretaceum the leaf has its lobes much produced, narrow, and running to a sharp point, as in the beautiful leaf shown on Plate VII, figure 1, of "Later extinct floras," which, however, is still referred to Sassafras cretaceum. Lesquereux's Sassafras acutilobum does not differ greatly from the leaf just mentioned except in the direction of the lobes, which is a questionable specific character. From this leaf it is no great jump to those trilobed forms which are referred to Aralia wellingtoniana, the chief difference being in the margin. Thus we have an interrelated series connecting those leaves which seem to show affinity to Sassafras with those which suggest Platanus, on one hand, and with others which suggest Cissites and Aratia, on the other.

While it may be considered probable that biologically the forms mentioned in the foregoing paragraphs, as well as others not cited, represent the variations of a single species of Upper Cretaceous tree or at least represent the leaves of closely affiliated species, it seems best with reference to systematic and especially stratigraphic paleobotany that most of the differentiations instituted by Lesquereux be perpetuated. Consequently the present series is limited to the typical material as defined and illustrated by the original describer.

Falling within these limits are a number of occurrences in the true Dakota sandstone and the Raritan and Magothy formations of the Atlantic Coastal Plain. The Cheyenne sandstone has furnished four specimens obtained near Medicine Lodge River, 2 miles west of Belvidere (2224), and one specimen from the left bank of the middle branch of Champion (Wildcat) Draw, half a mile south of Belvidere (2229).
POSITION UNCERTAIN.

Genus FEISTMANTELIA Ward.

Feistmantelia oblonga Ward.

Plate XLVII, figures 4, 5 .

Feistmantelia oblonga Ward, U. S. Geol. Survey Nineteenth Ann. Rept., pt. 2, p. 693, pl. 169, fig. 19, 1899.

In not proposing a specific name for the form of this genus found in the Cheyenne sandstone I emphasize the fact that the term Feistmantelia denotes merely a form of preservation and that the objects to which it is applied lack either stratigraphic or botanic value.

This genus and in fact the nominal species Feistmantelia oblonga were founded by Ward in 1899 for the reception of certain casts of obscure affinities, but evidently of a vegetable nature, from the Fuson formation of eastern Wyoming. No diagnosis was attempted, but an extended discussion was given of somewhat similar forms figured by previous authors from various geologic horizons. The American Cretaceous forms referred to this genus may be characterized as showing a rather close-set series of elliptical, fusiform, or cigar-shaped convex casts of concave cavities formed by the rhytidosis of various plant tissues. They vary considerably in size, from 0.6 to 2.5 centimeters in length by 0.35 to 1.0 centimeter in width, and are arranged in an irregular spiral, the irregularity being perhaps due to compression. They are thus overlapping or alternate in a horizontal direction and more or less linear in a vertical direction.

Somewhat similar remains occur at widely separated geologic horizons, and comparable objects with the markings inclined to be rhomboidal in form are not rare in the New Jersey Triassic deposits, where they are, according to Newberry, ${ }^{36}$ the decorticated trunks of some conifer, possibly Palissya. Similar remains are figured by Schauroth ${ }^{37}$ as trunks of Voltzia coburgensis and by Blanckenhorn ${ }^{38}$ as trunks of Voltzia heterophylla.

${ }^{36}$ Newberry, J. S., U. S. Geol. Survey Mon. 14, p. 94, pl. 26, figs. 1, 2, 1888 .

${ }^{37}$ Schauroth, Deutsch. geol. Gesell. Zeitschr., Band 4, p. 539, 1852. See Schenk, August, Palaeontographica, Band 11, p. 308, pl. 46, fig. 2, 1864. 38 Blanckenhorn, Max, Palaeontographica, Band 32, p. 135, pl. 22, figs. $18-20,1886$. 
Among the somewhat similar forms which Ward mentions are remains from Kukurbit, in Kach (Lias), described by Feistmantel ${ }^{39}$ as "portions of a stem of a coniferous plant." Next in point of similarity are certain English and German Wealden remains regarded as parts of Clathraria anomala, ${ }^{40}$ some of which are still referred by Seward ${ }^{41}$ to Bucklandia anomala, a later name for the same plant. The latter are undoubtedly medullary casts of cycadophyte trunks, a class of remains for which Saporta ${ }^{42}$ proposed the name Cycadeomyelon, describing one species from the infra-Lias of Hettange, near Metz (Moselle). ${ }^{43}$ Remotely similar remains from the Triassic of York County, Pa., are described by Fontaine ${ }^{44}$ as Cycadeomyelon yorkense, and the forms described by Newberry ${ }^{45}$ are referred to it, although Seward ${ }^{46}$ had shown that remains from abroad identical with these are to be interpreted as medullary casts of Voltzia. Similar remains were more recently discussed by Wills, ${ }^{47}$ who refigures one of the original specimens of Voltzia coburgensis. ${ }^{48}$ They are also practically identical in character, as Potonié ${ }^{49}$ has shown, with casts of the medullary cavities of certain existing Araucarias, notably Araucaria brasitiana. Other remains of this general sort, which, however, seem referable to the Cycadophyta, are Omphalomela scabra Germar, ${ }^{50}$ renamed by Schimper ${ }^{51}$ Clathraria? germari, and Cycadeoidea stillwelli Ward. ${ }^{52}$ As Seward has pointed out, Williamson ${ }^{53}$ figured very similar casts of the medullary cavity of Stigmaria, thus emphasizing the wide range in botanic affinity of objects of this kind.

\footnotetext{
${ }^{39}$ Feistmantel Ottokar, Fossil flora of the Gondwana system, vol. 2 pt. 1 , p. 61 , pl. 10 , fig. 2,1876 .

${ }^{40}$ Stokes and Webb, Geol. Soc. London Trans., 2d ser., vol. 1, pl. 46 fig. 8 ; pl. 47 , figs. $4 \mathrm{~b}, 4 \mathrm{c}, 1824$. See Schenk's figure of Clathraria lyelli Mantell, Palaeontographica, Band 19, p. 227, pl. 30, fig. 7, 1871.

11 Seward, A. C., Wealden flora, pt. 2, p. 123, 1895.

12 Saporta, Gaston de, Plantes jurassiques, tome 2, p. 331, 1875

43 Idem, p. 333 , atlas, pl. 49 , fig. 5 .

14 Fontaine, W. M., in Ward, L. F., U. S. Geol. Survey Twentieth Ann. Rept., pt. 2, p. 248, pl. 30, 1900.

${ }^{4}$ Newberry, J. S., op. cit.

${ }^{46}$ Seward, A. C., Geol. Mag., dec. 3, vol. 7, pp. 218-220, fig. 1, 1890

47 Wills, L. J., Geol. Assoc. Proc., vol. 21, pp. 292-294, 1910.

48 Idem, pl. 17, fig. 6.

49 Potonié, H., K. preuss. geol. Landesanst. Jahrb., 1887, pp. 311-331, pls. 12-13a.

50 Germar, E. F., Palaeontographica, Band 1, p. 3, 1846

51 Schimper, W. P., Paléontologie végé le, tome 3, p. 554, 1874.

52 Ward, L. F., U. S. Geol. Survey Tweni:eth Ann. Rept., pt. 2, p. 636 pl. 149, 1900.

${ }^{53}$ Williamson, W. C., A monograph on the morphology and histology of Stigmaria ficoides, pl. 13, figs. 64, 65, Palaeont. Soc., 1887.
}

Turning now to the Cretaceous remains to which the genus, if used at all, should be restricted (although Ward has the temerity to rename Feistmantel's Indian Liassic fossil Feistmantelia fusiformis), we may note that in addition to the type species from the Fuson formation, Fontaine ${ }^{54}$ has described an additional species from the Patuxent formation at Cockpit Point, Va., which is really indistinguishable from the type species, and Ward ${ }^{55}$ has mentioned the occurrence of similar objects from Kansas at a higher Cretaceous horizon. Still more recently Hollick and Jeffrey ${ }^{56}$ have described comparable remains with structure preserved from the upper Raritan of Kreischerville, Staten Island, and have demonstrated their coniferous nature, naming their material Pinus sp.? Some of this material is said to have been found in organic connection with wood showing the characters of Pitoxylon. It is not altogether clear that the Lower Cretaceous species of Feistmantelia are of the same nature as that described by Hollick and Jeffrey, although these authors have furnished the presumption that they are all casts of the interstitial cavities of the periderm network of the bark, due to decay, in some conifer. That they should be referred to Pinus, even for individual specimens, seems unwise, and the genus Feistmantelia is here retained as a convenient form genus for remains of this sort, which may represent various modern coniferous genera. Indistinguishable remains occur in the Tuscaloosa formation of Alabama, although I did not consider them of sufficient importance to include them in my paper on the Tuscaloosa flora. ${ }^{57}$ They are also present at as recent a horizon as the upper part of the Black Creek formation in North Carolina. These also I did not consider of sufficient interest to include in my account of that flora, but $I$ am including here a figure of a North Carolina specimen for comparison with one from the Cheyenne sandstone, to show that the latter is without stratigraphic value.

51 Fontaine W. M., in Ward, L. F., U. S. Geol. Survey Mon. 48, p. 484, pl. 107, fig. 3, 1906

${ }_{55}$ Ward, L. F., U. S. Geol. Survey Nineteenth Ann. Rept., pt. 2, p. 694, 1899.

${ }_{56}$ Hollick, Arthur, and Jeffrey, E. C., New York Bot. Garden Mem., vol. 3 , p. 17, pl. 3, fig. 8 ; pl. 22, fig. 5, 1909 .

$5 i$ Berry, E. W., U. S. Geol. Survey Prof. Paper 112, 1919. 
The Cheyenne material contained in the present collection comes from Champion (Wildcat) Draw, three-fourths mile south of Belvidere (2222), and hills between Spring Creek and Soldier, 4 miles northeast of Belvidere, where it is extremely abundant.

\section{Genus CARPOLITHUS of authors.}

Carpolithus belviderensis Berry, n. sp.

Plate XLI, figure 4.

This species is based on a single characteristic specimen, which is entirely distinct from anything previously described. It represents a large pyriform pedunculate pyxidium 1.8 centimeters in length and 13.5 millimeters in maximum diameter. The peduncle is curved and stout, about 1 centimeter in length. The pyxidium is pointed proximad, widest and flatly rounded distad. The sides are distinctly fluted with twelve or thirteen rounded nodes separated by shallow rounded sinuses. The ribbing may indicate parietal placenta or a loculicidal habit, although the latter alternative appears to be negatived by the lid.

It is possible that this conspicuous and characteristic fruit may not have been a true pyxidium and shed its seeds by loosening of the lid, as in Eucalyptus, but that it was a capsule like that of Papaver and the small parietal seeds were discharged through openings beneath the so-called lid, which may represent a concrescent stigma. The specimen comes from Stokes Hill, northeast of Belvidere (2220). 
PLATES XLVII-LXI. 



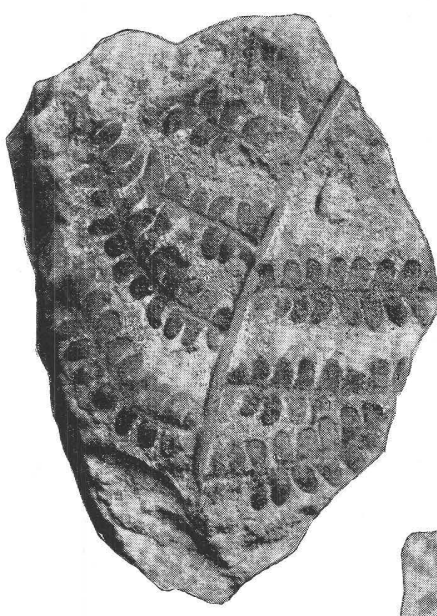

1

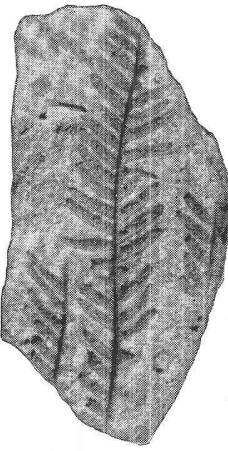

2

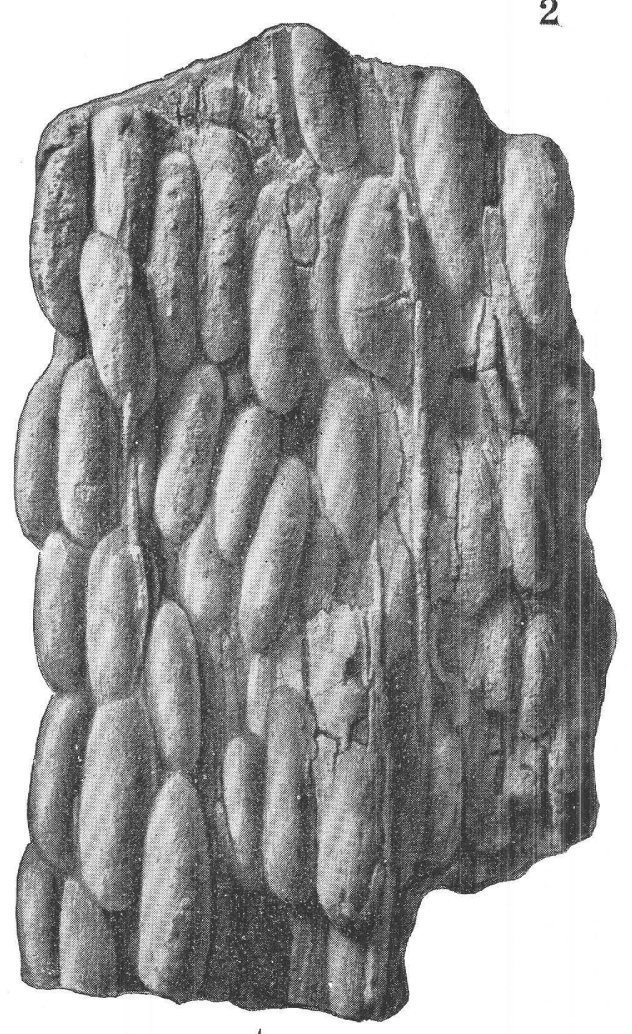

4

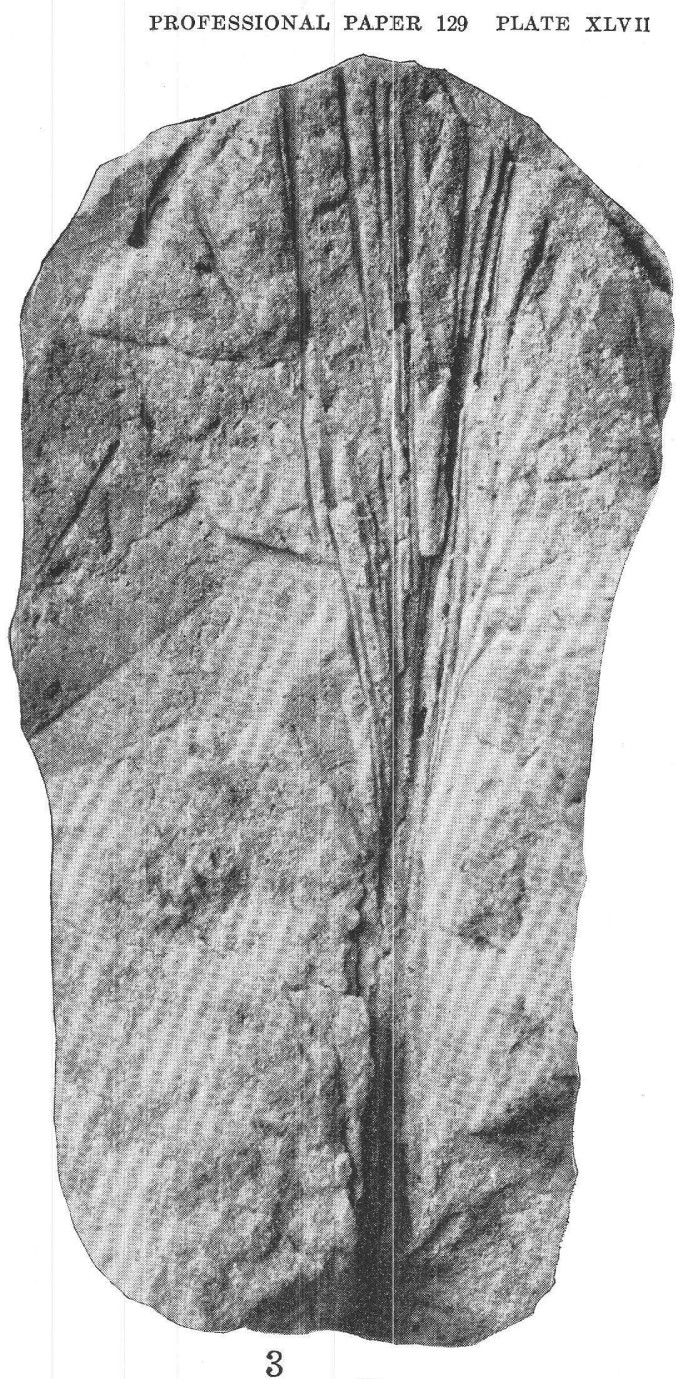

3

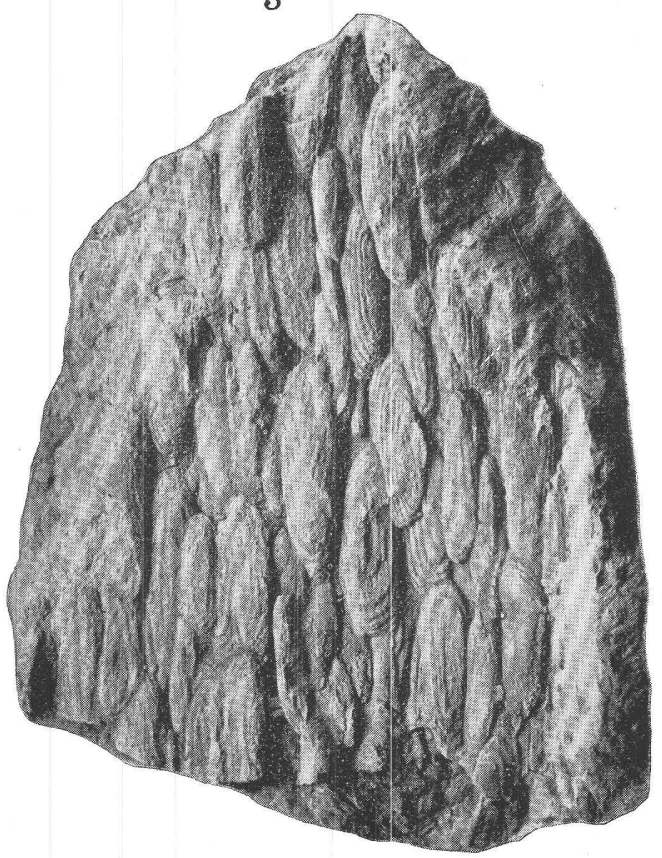

5

FOSSIL PLANTS FROM THE CHEYENNE SANDSTONE.

1, Gleichenia nordenskioldi Heer; 2, Fleichenia (?) bohemica (Corda) Berry; 3, Abietites longifolius (Fontaine) Berry; 4,5 , Feistmantelia oblonga Ward. All the specimens are from the Cheyenne sandstone near Belvidere, Kans., except
that shown in figure 4, which is from the Black Creek formation of North Carolina. 

U. S. GEOLOGICAL SURVEY

PROFESSIONAL PAPER 129 PLATE XLVIUI

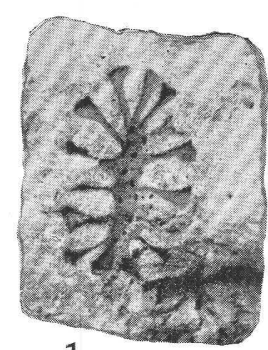

1

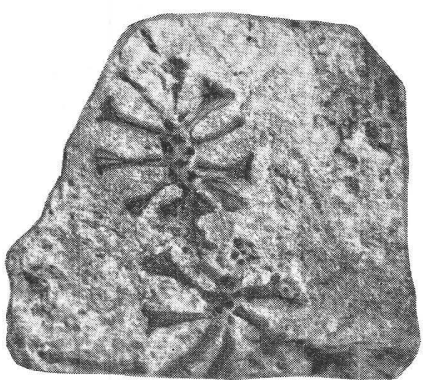

3

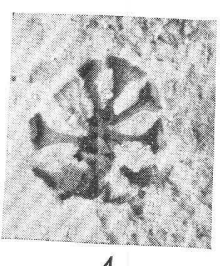

4

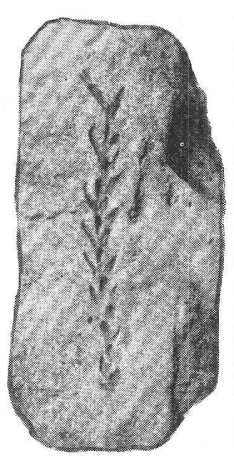

5
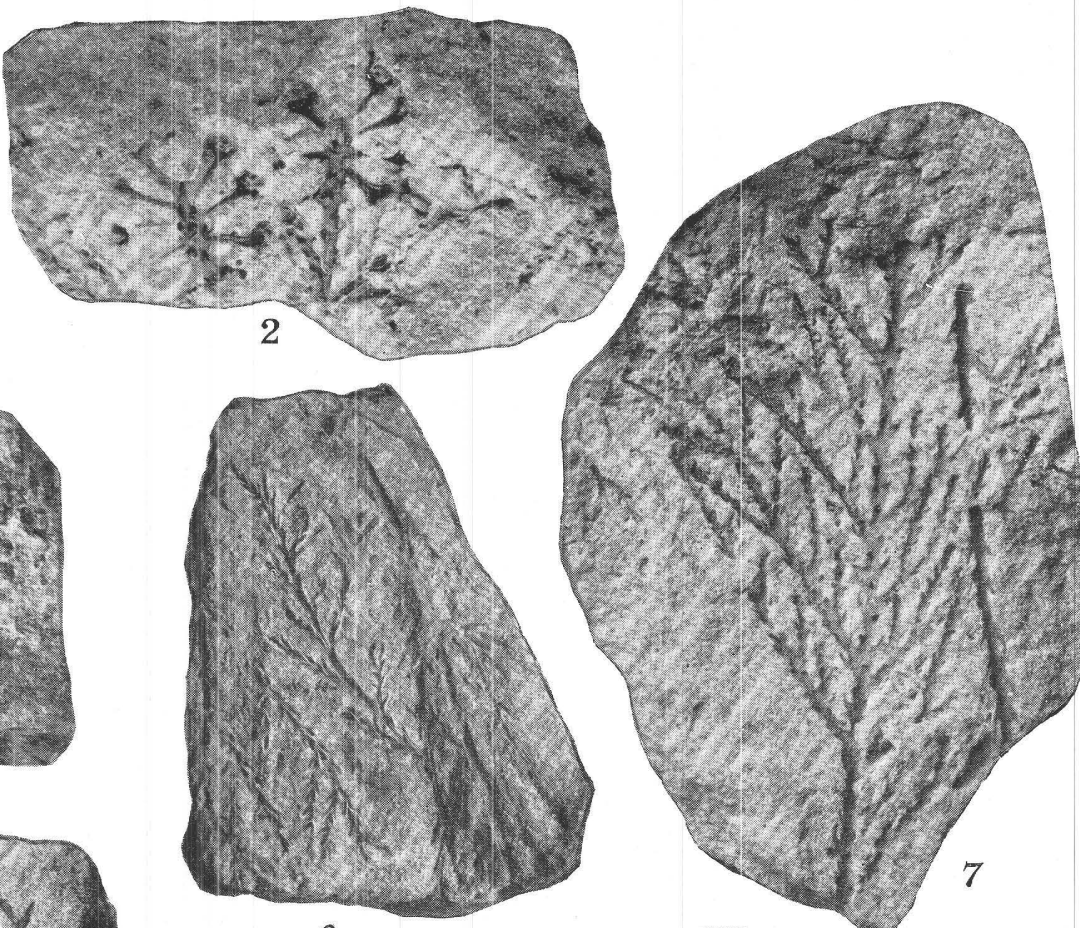

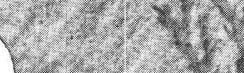

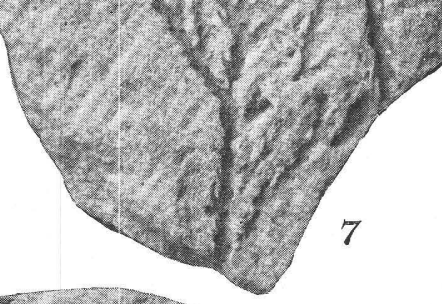

6

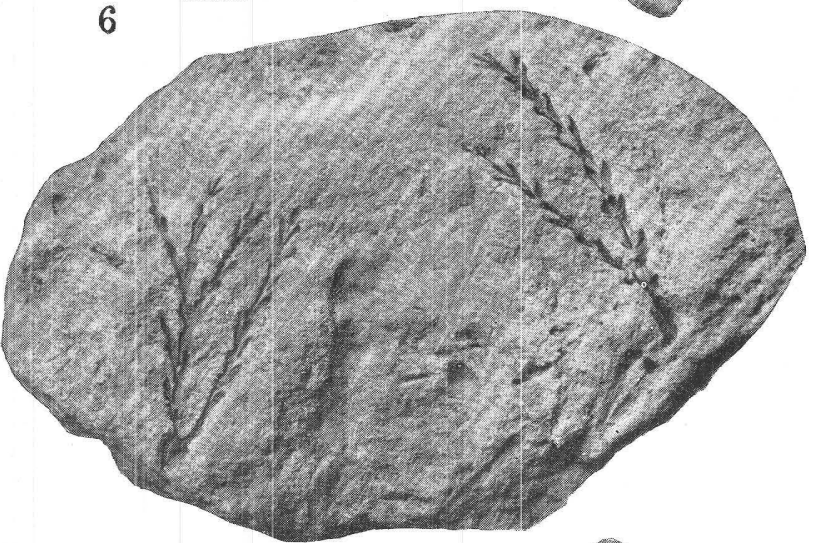

8

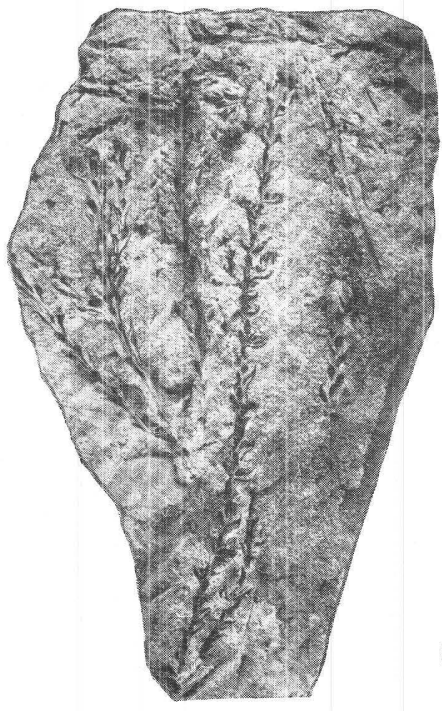

10

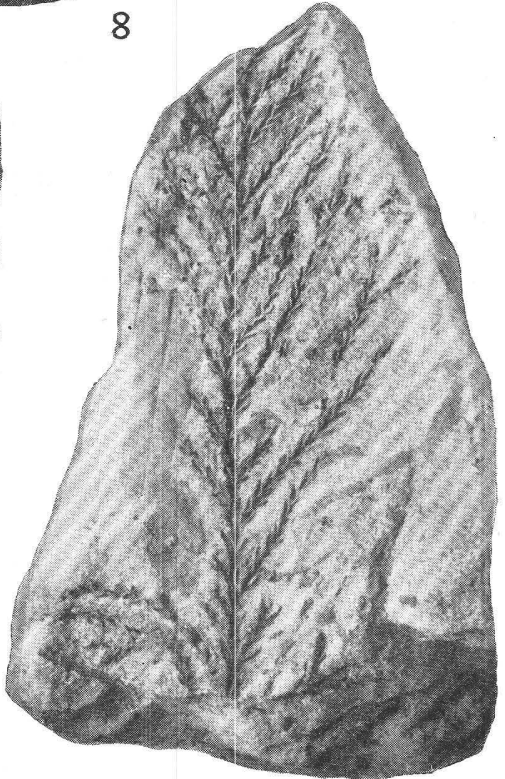

11.

CONES AND FOLIAGE OF SEQUOIA CONDITA LESQUEREUX.

From Cheyenne sandstone at several localities near Belvidere, Kans. 

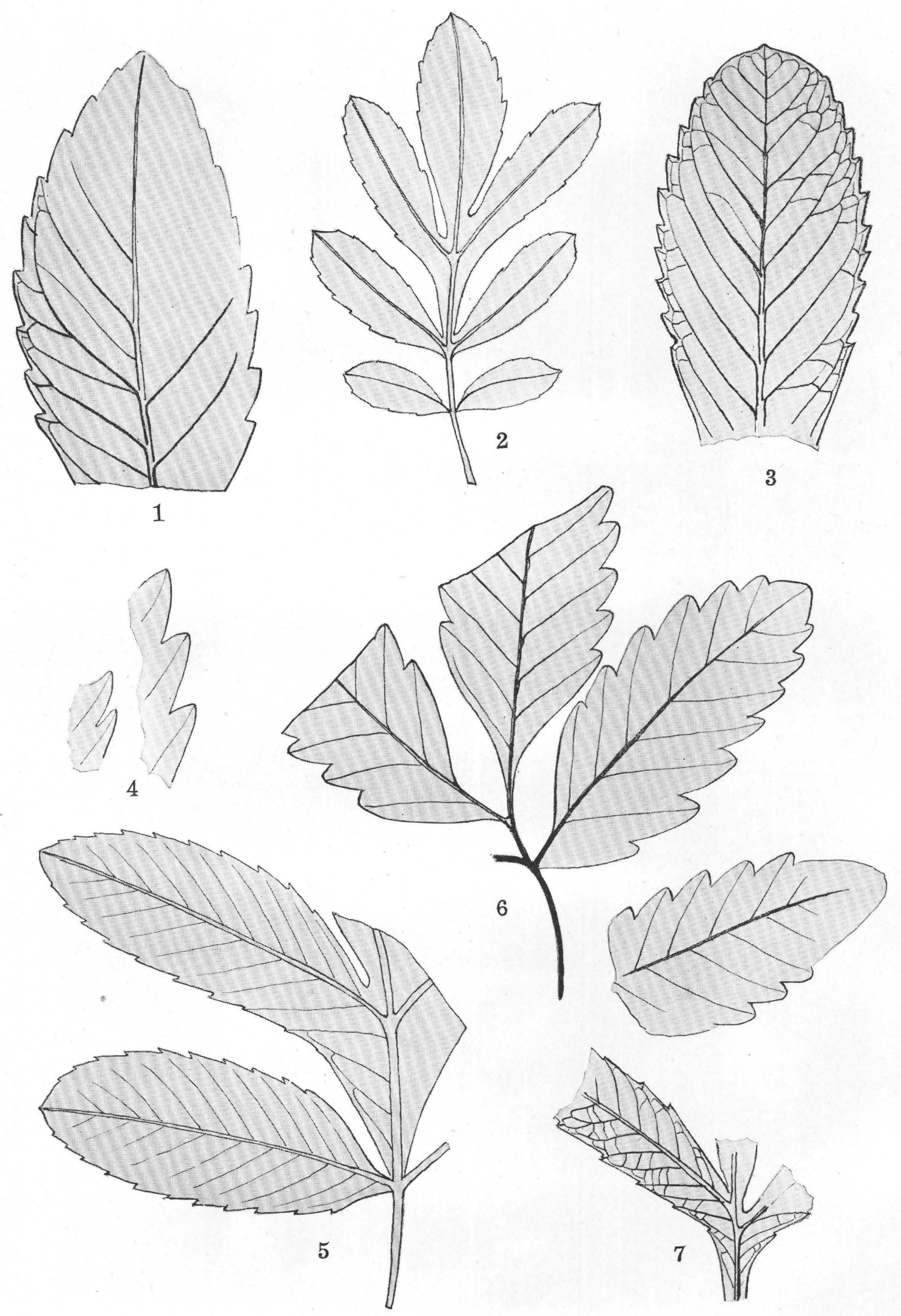

SAPINDOPSIS BELVIDERENSIS BERRY.

From Cheyenne sandstone near Belvidere, Kans. 
U. S. GEOLOGICAL SURVEY

PROFESSIONAL PAPER 129 PLATE L

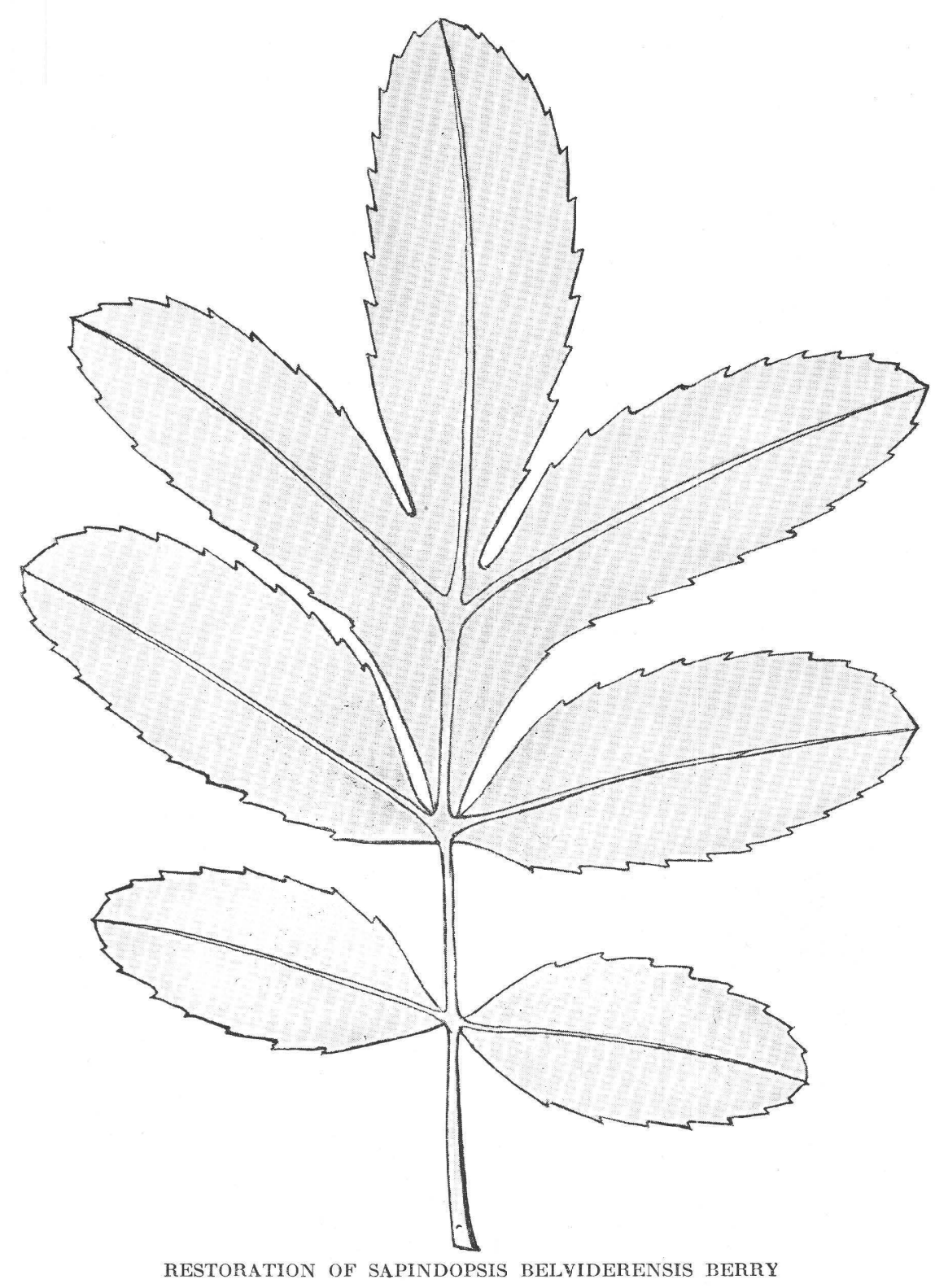




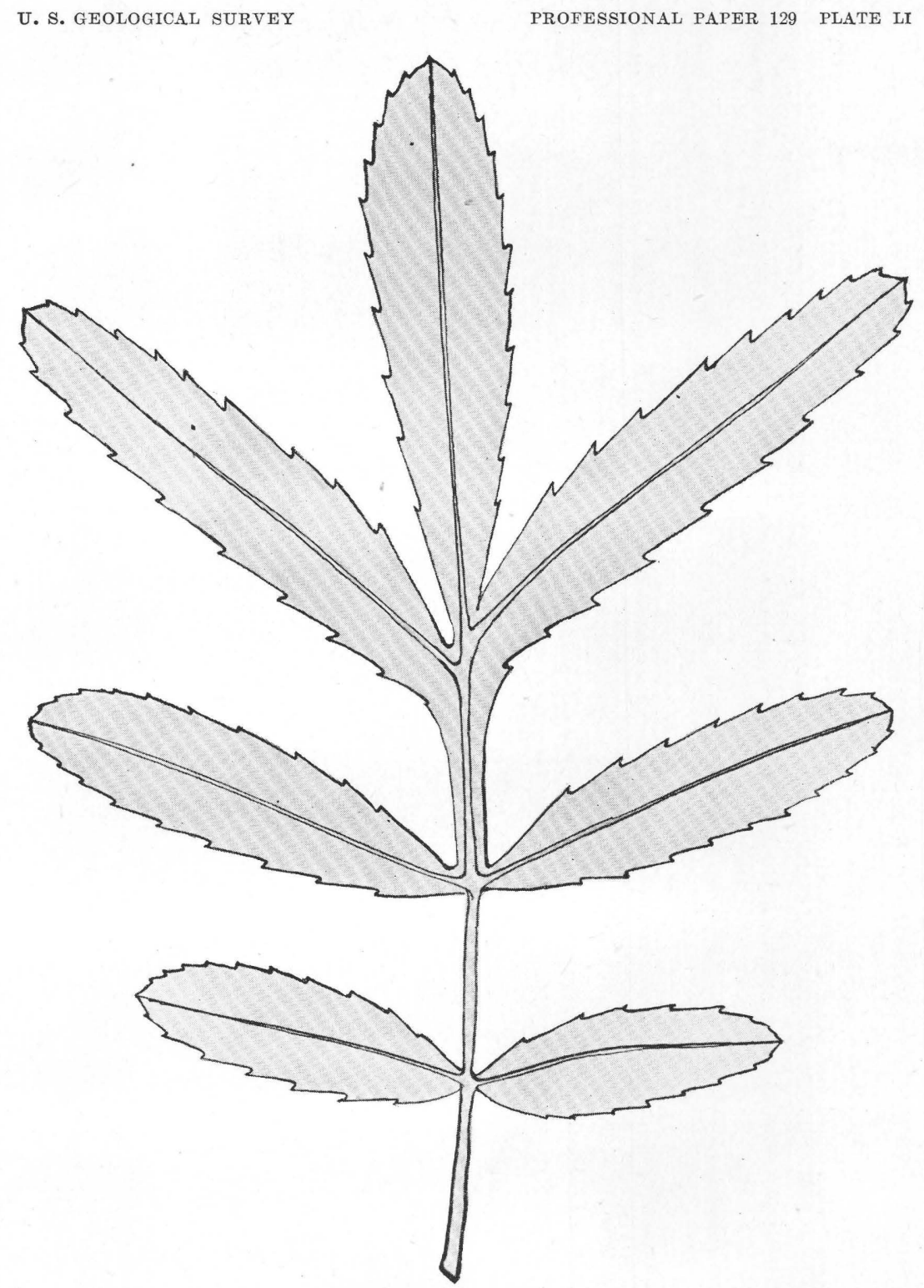

RESTORATION OF SAPINDOPSIS BELVIDERENSIS BERRY。 


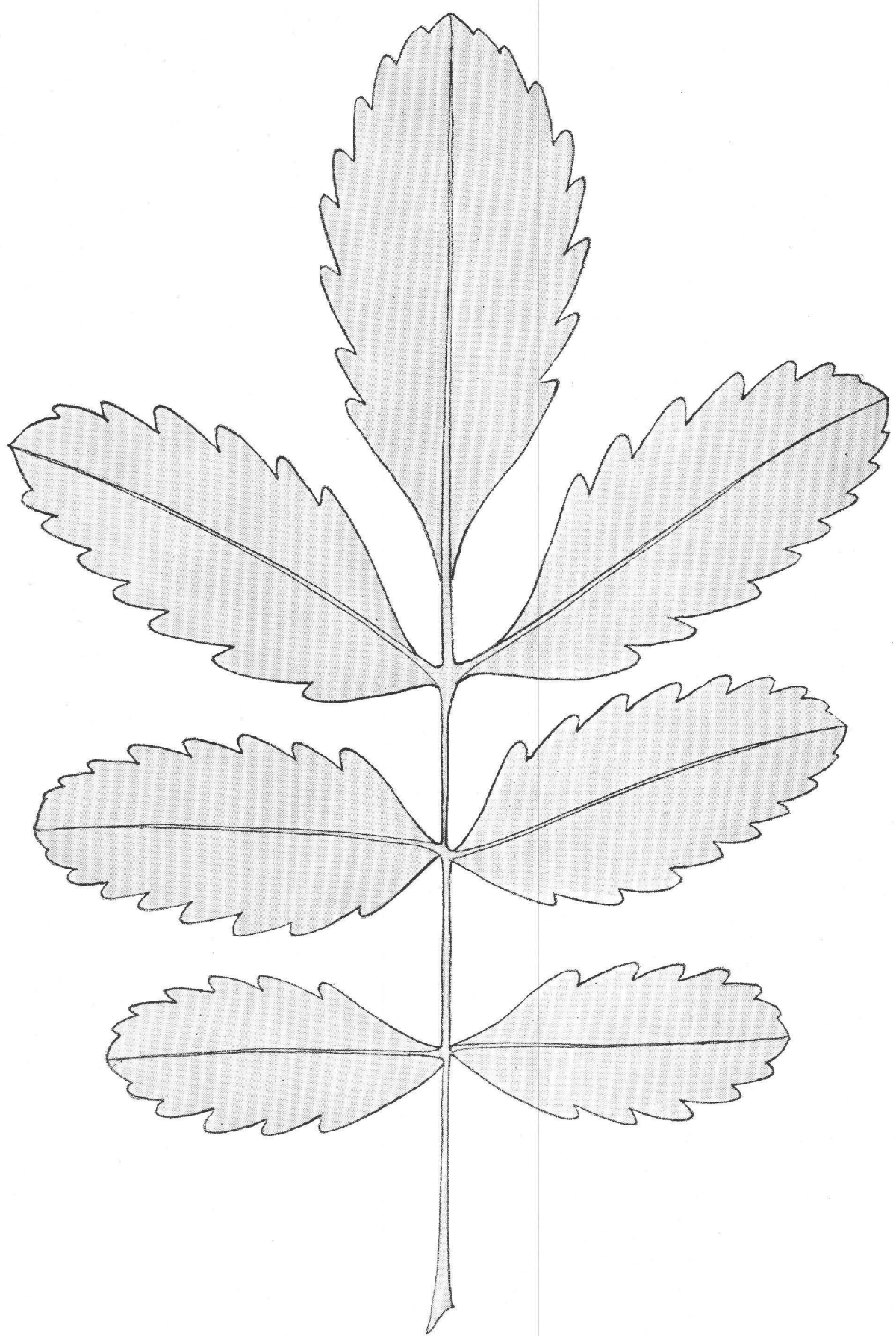

RESTORATION OF SAPINDOPSIS BEIVIDERENSIS BERRY. 


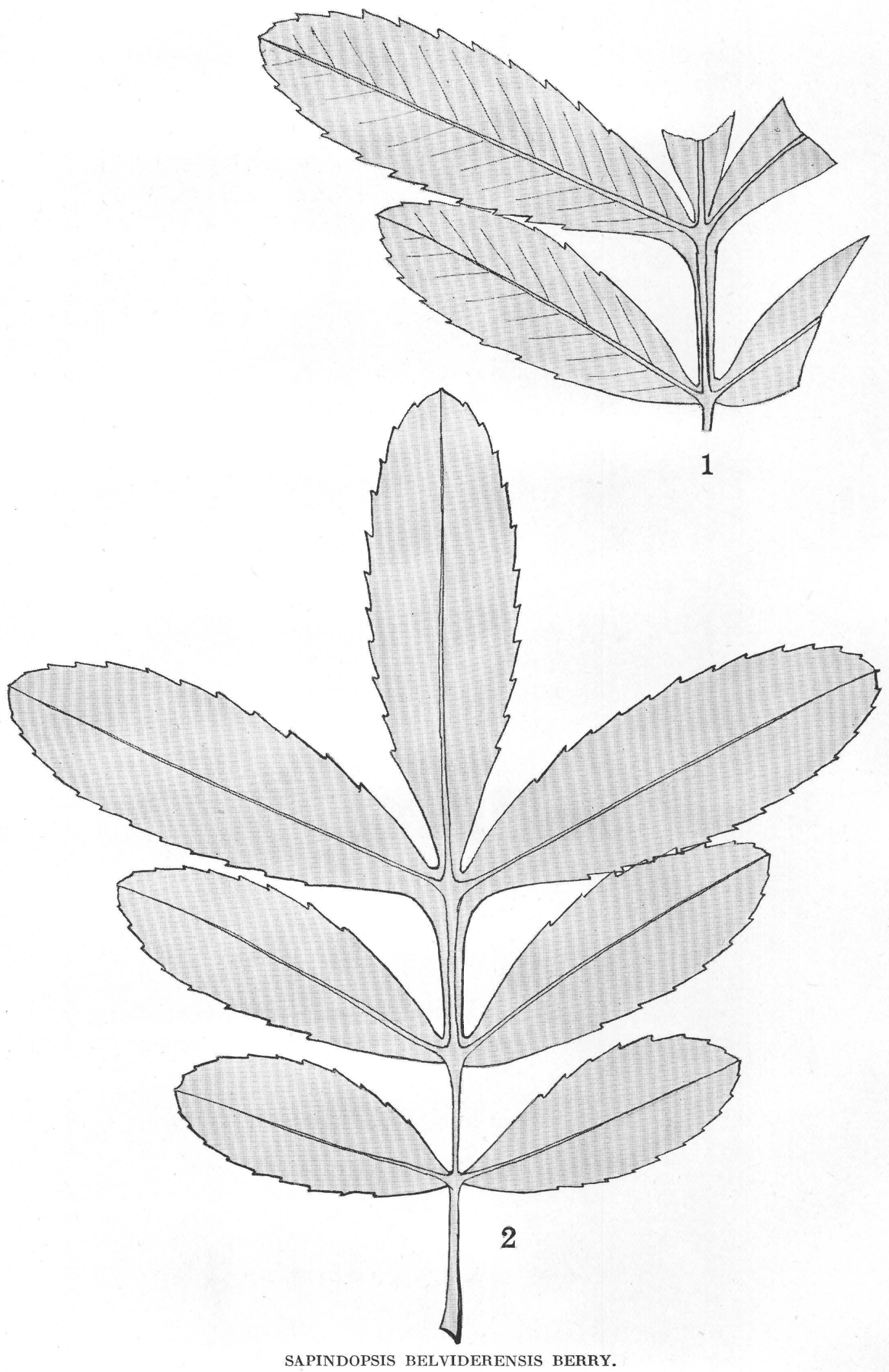

1, Specimen obtained near Belvidere, Kans.; 2, restoration of specimen shown in figure 1. 
U. S. GEOLOGICAL SURVEY PROFESSIONAL PAPER 129 PLATE LIV

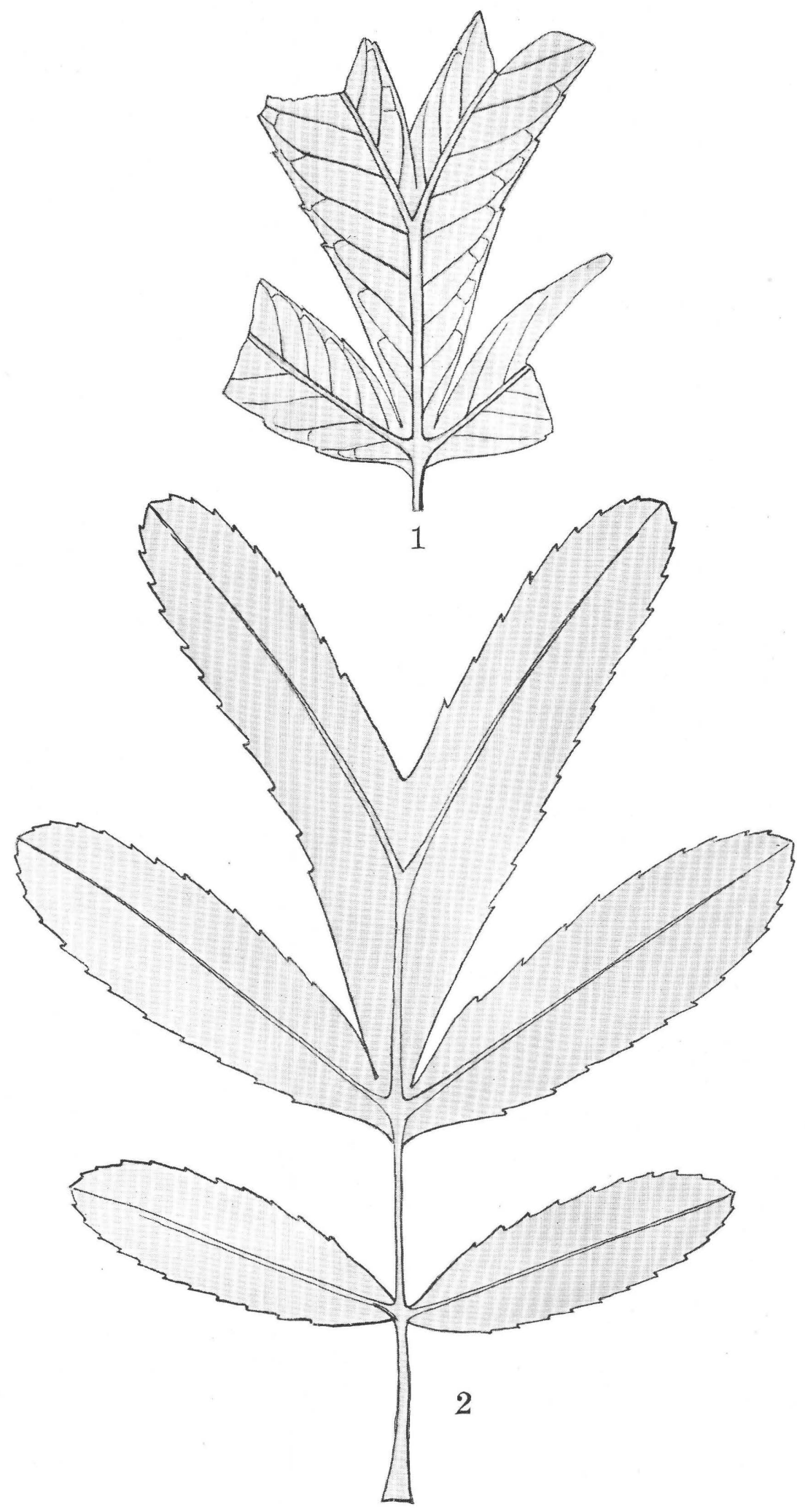

SAPINDOPSIS BELVIDERENSIS BERRY.

1, Specimen obtained near Belvidere, Kans.; 2, restoration of specimen shown in figure 1. 

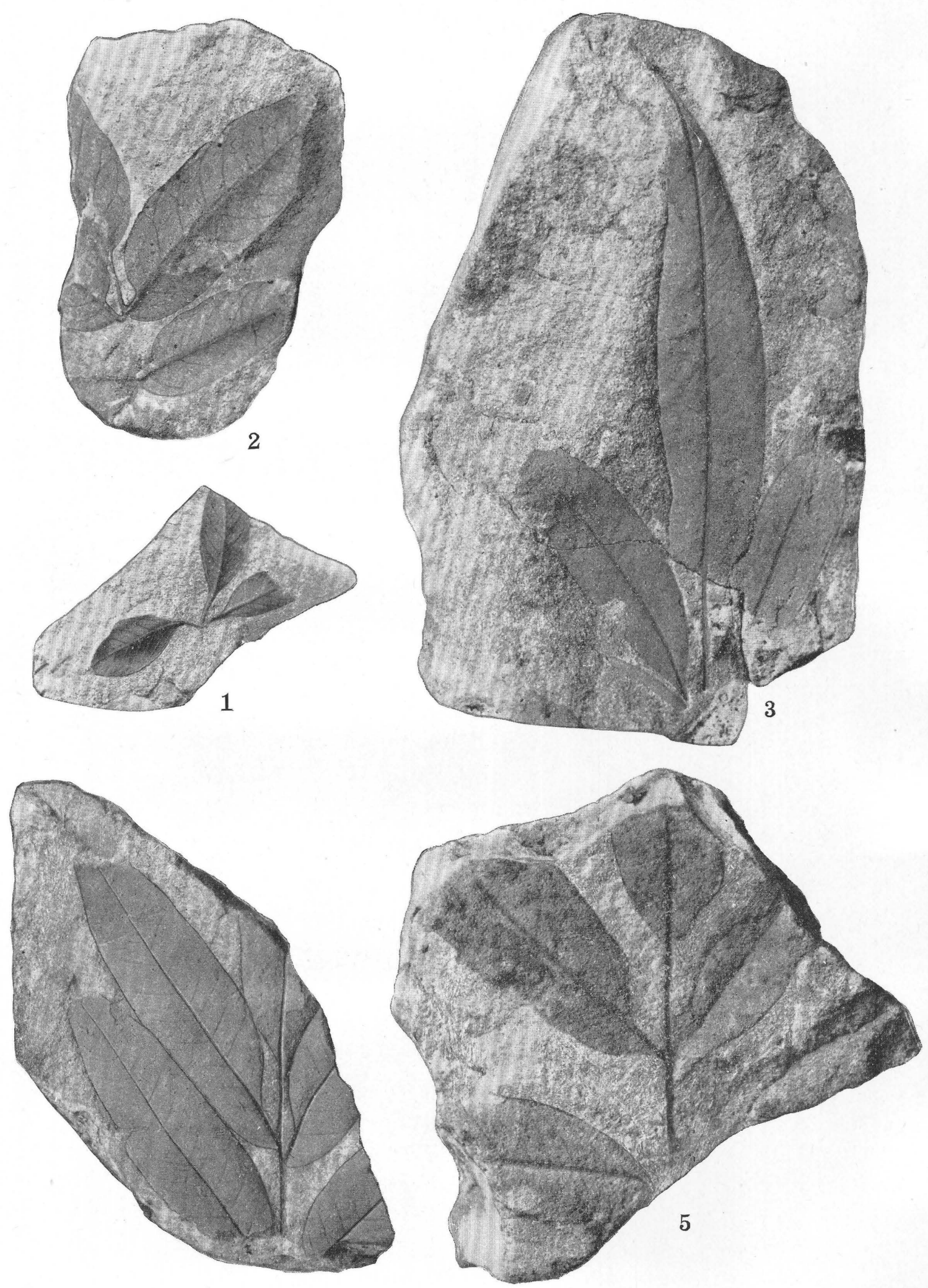

4

FOSSIL PLANTS FROM THE CHEYENNE SANDSTONE. 1, Sapindopsis brevifolía Fontaine; 2-4, Sapindopsis variabilis Fontaine; 5, Sapindopsis magnifolia Fontaine. All collected near
Belvidere, Kans. 

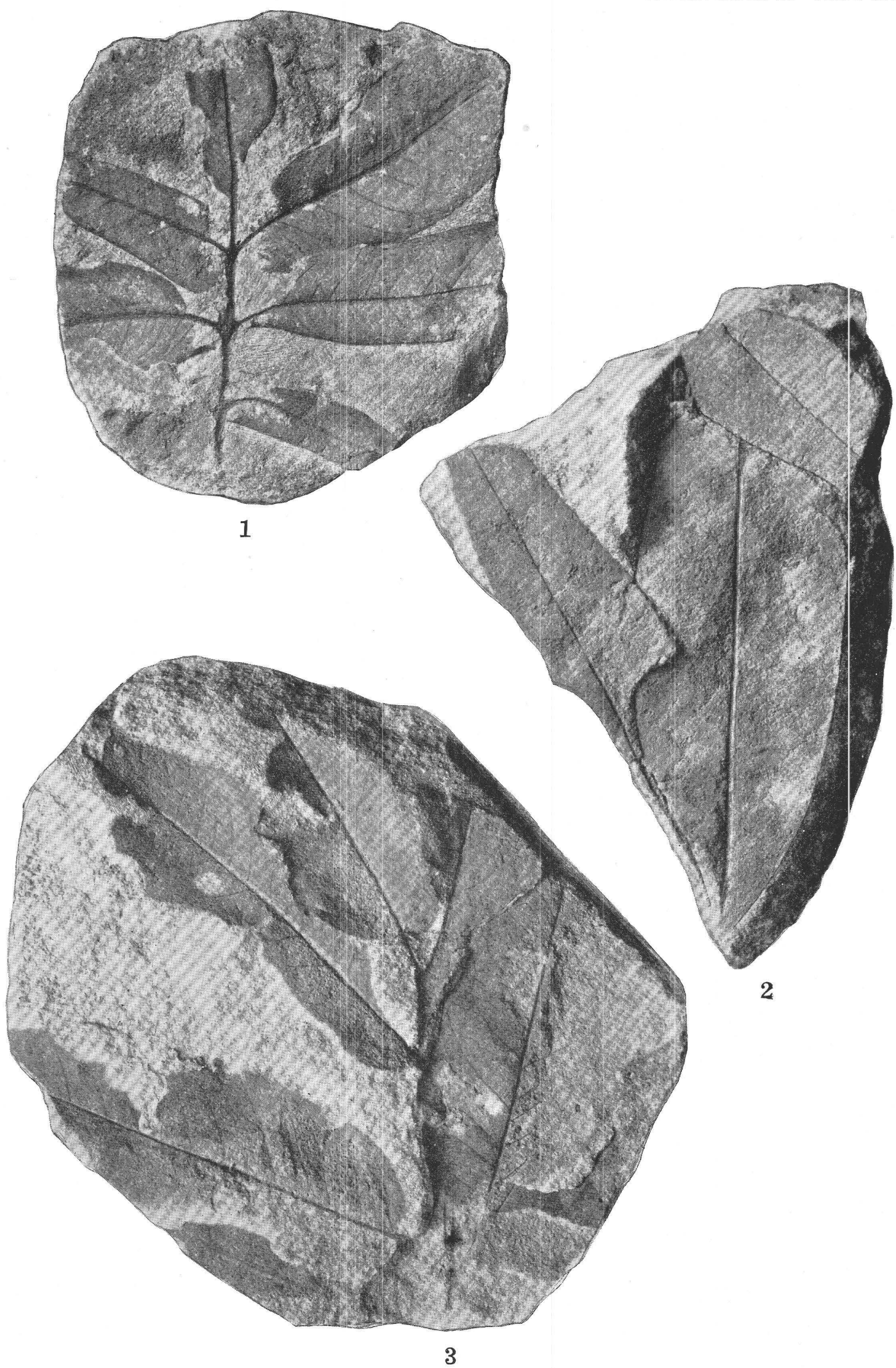

2

SAPINDOPSIS MAGNIFOLIA FONTAINE.

From Cheyenne sandstone near Belvidere, Kans. 


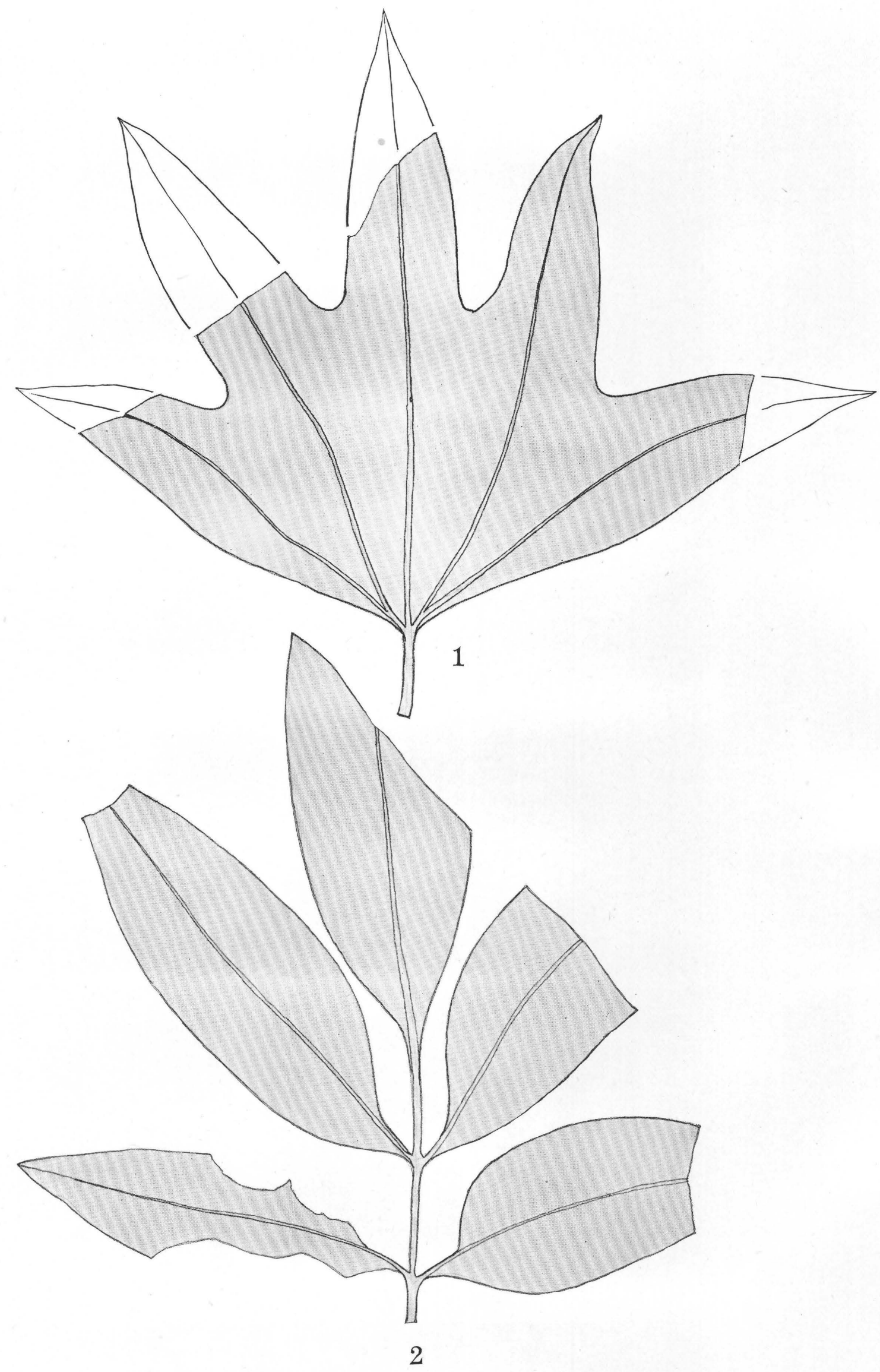

FOSSIL PLANTS FROM THE CHEYENNE SANDSTONE.

1, Sterculia towneri (Lesquereux) Berry; 2, Sapindopsis magnifolia Fontaine. Collected near Belvidere, Kans. 


\section{U. S. GEOLOGICAL SURVEY}

PROFESSIONAL PAPER 129 PLATE LVIII

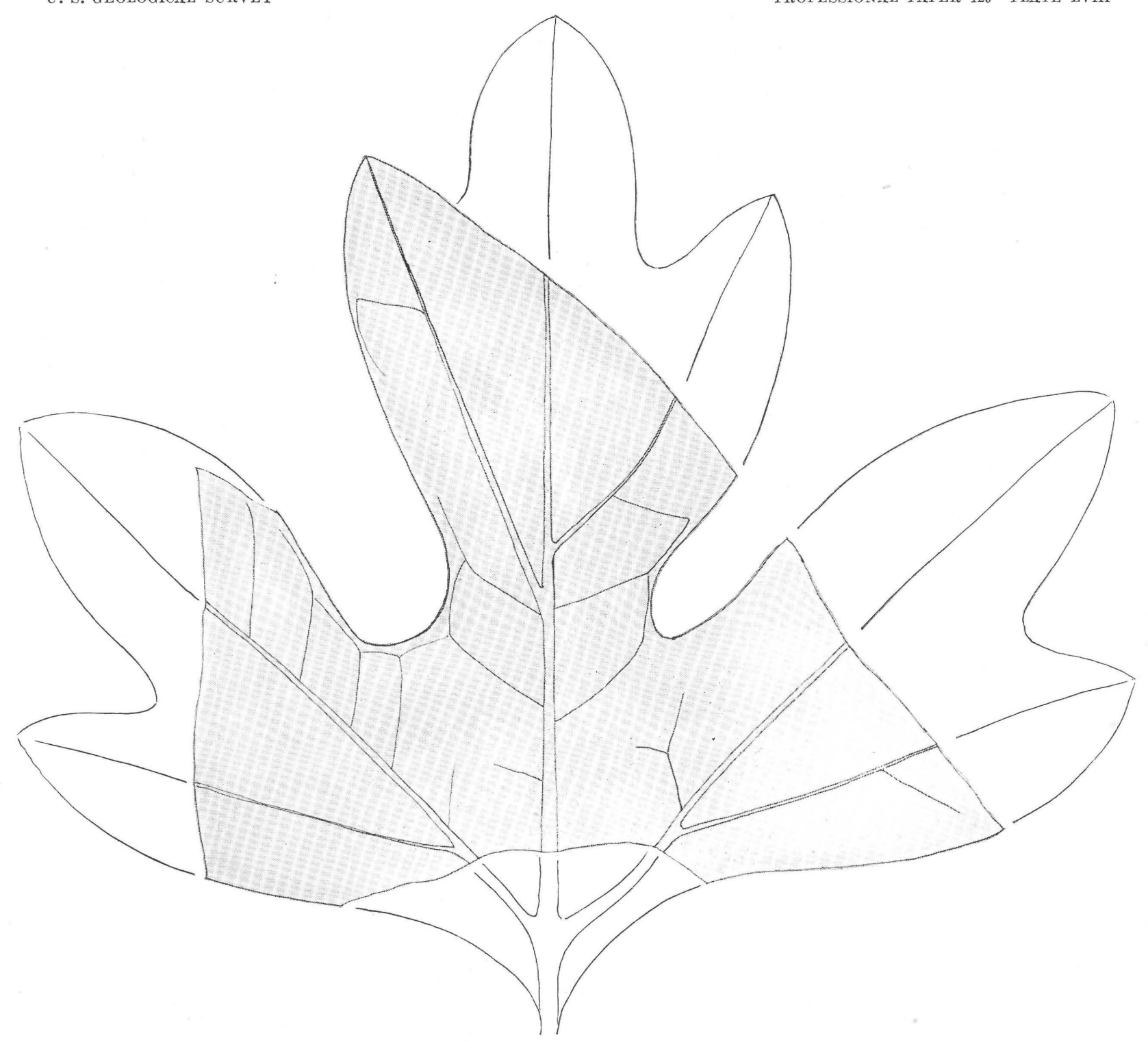

ARALIA RAVNIANA HEER.

From Cheyenne sandstone near Belvidere, Kans. About four-fif ths natural size. 

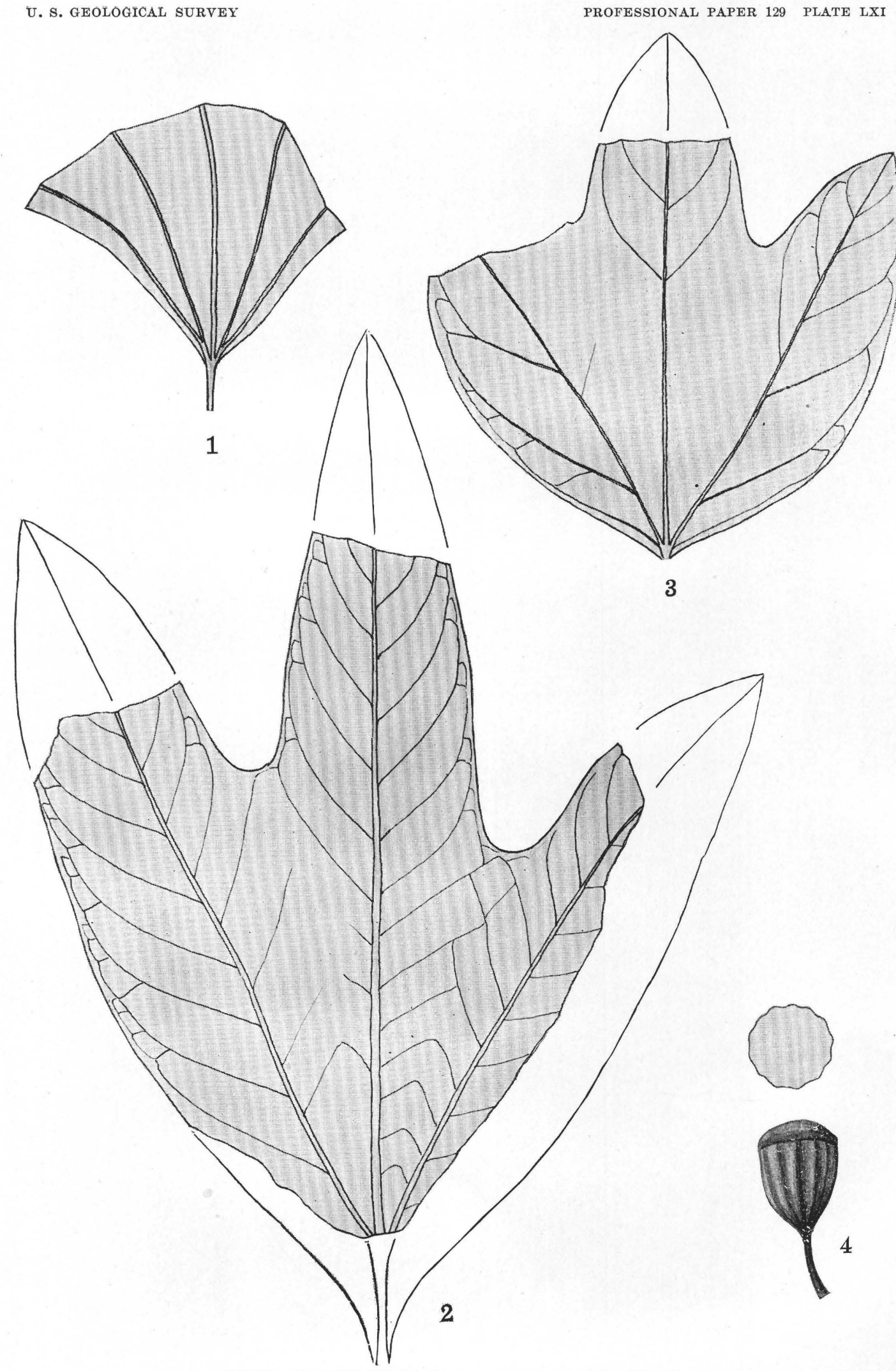

FOSSIL PLANTS FROM THE CHEYENNE SANDSTONE.

1, Stercuiia towneri (Lesquereux) Berry; 2, Araliopsoides cretacea (Newberry) Berry; 3, Sassafras mudgii Lesquereux; 